\title{
INTERPRETING AND PRESERVING THE WORK OF ROBERTO BURLE MARX: IN SEARCH FOR NEW APPROACHES
}

Rossana Vaccarino

Arquiteta paisagista e professora assistente de Arquitetura Paisagística na Universidade de Harvard (EUA) de 1994 a 1999. Atualmente é pesquisadora associada nesta universidade.

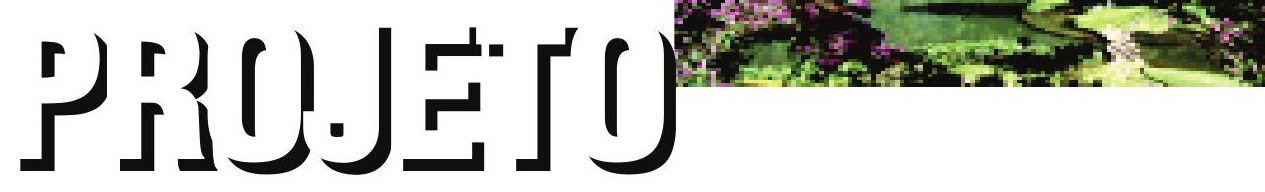




\section{RESUMO}

O texto se refere a uma palestra proferida no IV ENEPEA - Encontro Nacional de Ensino em Escolas de Arquitetura e Urbanismo no Brasil, em outubro de 2000, que objetivou colocar um entendimento sobre o modo de projetar de Roberto Burle Marx, emblemáticos, os parques privados das fazendas Marabaia e Vargem Grande (RJ), os parques do Flamengo (RJ) e del Este (Caracas - Venezuela) e o Sítio Santo Antônio da Bica - Sítio Burle Marx também na cidade do Rio de Janeiro. Com base em seus projetos, Burle Marx adotou sete princípios básicos: a complexidade de seus planos de plantio, a estruturação física dos espaços por massas de plantas, a necessidade de conhecer, e portanto, explorar a vegetação das áreas nas quais novos projetos eram feitos, a necessidade de um viveiro como base de apoio, o treinamento de bons jardineiros dedicados ao projeto, o uso de espécies jovens e o esclarecimento de um processo de manutenção ativo.

\section{ABSTRACT}

This paper is the result of a conference in the IV ENEPEA - Encontro Nacional de Ensino de Paisagismo em Escolas de Arquitetura, in october 2000, which focused the Burle Marx's design guidelines of private gardens and parks in Brazil. The main subjects are the gardens of Fazendas Marabaia, Vargem Grande, Sítio Santo Antônio da Bica and two of the main important Burle Marx's projects - the parks Aterro do Flamengo (Rio de Janeiro, Brasil) and del Este (Caracas, Venezuela). The paper also indicated the seven main design principles of Burle Marx - the complexity in planting design; the space organization by plants; the necessity of specific studies and knowledge about the site's vegetation; the use of juvenile specimens; the necessity of excellent gardeners; a continuous maintenance process and the existence of a good nursery. 


\section{INTERPRETING AND PRESERVING THE WORK OF ROBERTO BURLE MARX: IN SEARCH FOR NEW APPROACHES}

\section{Introduction}

The legacy of Roberto Burle Marx in brazilian landscape architecture is in danger of being lost because of the many challenges that surround the interpretation and preservation of his numerous projects. Two among the most important issues to consider are, first, the progressive alteration or disappearance of Burle Marx's gardens and open spaces, and second, the lack of access to primary sources and drawings that could help interpret many built projects, especially those before the1950s. Moreover, a number of drawings or models have been lost in Burle Marx's travelling exhibitions around the world, others were loaned and never returned, or were donated to friends.

When a project has not been destroyed and drawings are indeed available, a third challenge presents itself: the drawings do not reflect what was actually built. Often even the plants listed in the original plant lists have not been used, or different species have been substituted. These inconsistencies exist because Burle Marx built and re-built several projects over the course of his career without making a record of the changes that he implemented. He frequently worked directly on-site without the mediation of construction drawings (like measured site plans, planting plans, or sections). Burle Marx in fact liked to engage the landscape as a creative process, as a moving target, as a fragile and perishable entity always developing and transforming in time. In this sense, the "original" plan, if produced, was for him more of an intention, a point of departure, and never a document to be followed literally.

What we often mistakenly think is the original plan, actually was something that was produced after construction. In fact, as projects were conceived and built, Burle Marx with the help of his associates would produce painterly renditions or models to be exhibited nationally and internationally as art, all along his paintings, sculptures, tapestries or fabric dyes. If there was an early plan made already, this would often be re-produced in another version, often even disre- 
garding the changes occurred since the first scheme in the choice of the plant used or other formal changes occurred during constructions. At times, the color painted in the groundcover masses in his gouache plans was selected for the artistic need of color contrast and composition in the drawing rather than for the purpose of depicting the color of the plant eventually used on site. In other words, the project idea was fixed in his genius somewhere, in two-dimension, independent from time and the built reality of the project.

On the other hand, Burle Marx clearly was interested in the landscape as a creative act rather than static artifact - a garden for him was precisely the act of its making, a deep creative experience, and a process of discovery. Many of his best projects are, in fact, the ones in which Burle Marx was able to intervene and make revisions all along: the interruptions during construction or the delayed implementation would be in fact moments for reflection, development, and incorporation of new ideas. In all this lie an apparent paradox: while his plan-gouaches and other artistic representation tended to fix in history his landscapes in two dimensions, the built projects were always changing, and were allowed to change by him, in time, and in threedimension. They were always in a state of changing physiognomy, so to speak, defying the possibility of authentication of an original form, in a particular moment. This aspect challenges traditional notions of preservation and conservation, because it is nearly impossible and often unproductive to date and associate Burle Marx's work with a particular time in history, and also with a particular drawing!

Indeed, it is quite difficult to preserve or restore his projects to an "original" scheme, since Burle Marx said himself that there is no original in his work to refer to, to come back to. Additionally, authenticity should not be understood stylistically here, even if Burle Marx's work is stylistically distinguished and recognized. As a consequence, preservation efforts focussing on a literal recovery of the forms and materials of what was "first" or "originally" produced would not only be difficult, but often inappropriate. A more successful approach may concentrate on the understanding and protection of the central idea behind each project. The preservation of the conceptual idea rather than the garden "object" allows for the development of conservation strategies that present history not only in its reference to the past, but also in its present and future connotations. I want to stress that it is not easy to interpret what might have been the essential conceptual ideas behind Burle Marx's work. This, in fact, requires the creation of a much more serious research and scholarship on Burle Marx, one able to 
analyze much more in depth his multifaceted design process and his peculiar way of working across disciplines.

I will now exemplify a number of key aspects I believe are important in the interpretation and conservation efforts of Burle Marx's work. I will talk only briefly about the implications that this approach may have in any program of landscape restoration and maintenance, leaving this topic for further discussion. I will first show a few key concepts in the design of two gardens that I studied in the early part of my research: Fazenda Marambaia and Fazenda Vargem Grande. It was in these gardens that I first encountered the paradox I mentioned before of the disparity between drawing and built work. Then I will use two famous parks - Parque Flamengo in Rio and Parque del Este in Caracas, Venezuela - to direct the attention to some of the issues I believe we should focus today in their preservation, issues that are not necessarily related to composition or form. I will end my essay with the questions raised by an important and much discussed site, today under conservation as a "museum". This is perhaps one of the most exemplary projects made by Burle Marx during his life, one that he implemented slowly since 1949, and which is now perhaps among the most endangered of all: The sítio Santo Antonio da Bica, or called today, Sítio Burle Marx.

\section{The Correspondence Between Context and Time: Two Gardens}

In january 1995 I visited Brazil for the first time to experience directly a number of Roberto Burle Marx's most important projects in Rio de Janeiro and São Paulo. To my disappointment, many of the gardens were in a state of disrepair or no longer existed. Two gardens, however, struck my attention: the garden of Fazenda Marambaia and the garden of Fazenda Vargem Grande (Figures 1 and 2). These gardens were mature landscapes that had spatial qualities and details not conveyed in their original drawings or in published photographs. While the Marambaia garden, built just before the acquisition of Burle Marx's sítio in 1949, was surprisingly at a most splendid phase in its evolution, the garden of Vargem Grande, whose first plan was much later and is dated 1979, appeared to be unfinished, and already in an initial state of decline from lack of proper maintenance.

Both located in rural settings, these two gardens share the Mata Atlantica as their larger environment, and are more precisely located within two distinct ecological forest formations, both seriously threatened by human action and in fact today protected as national 


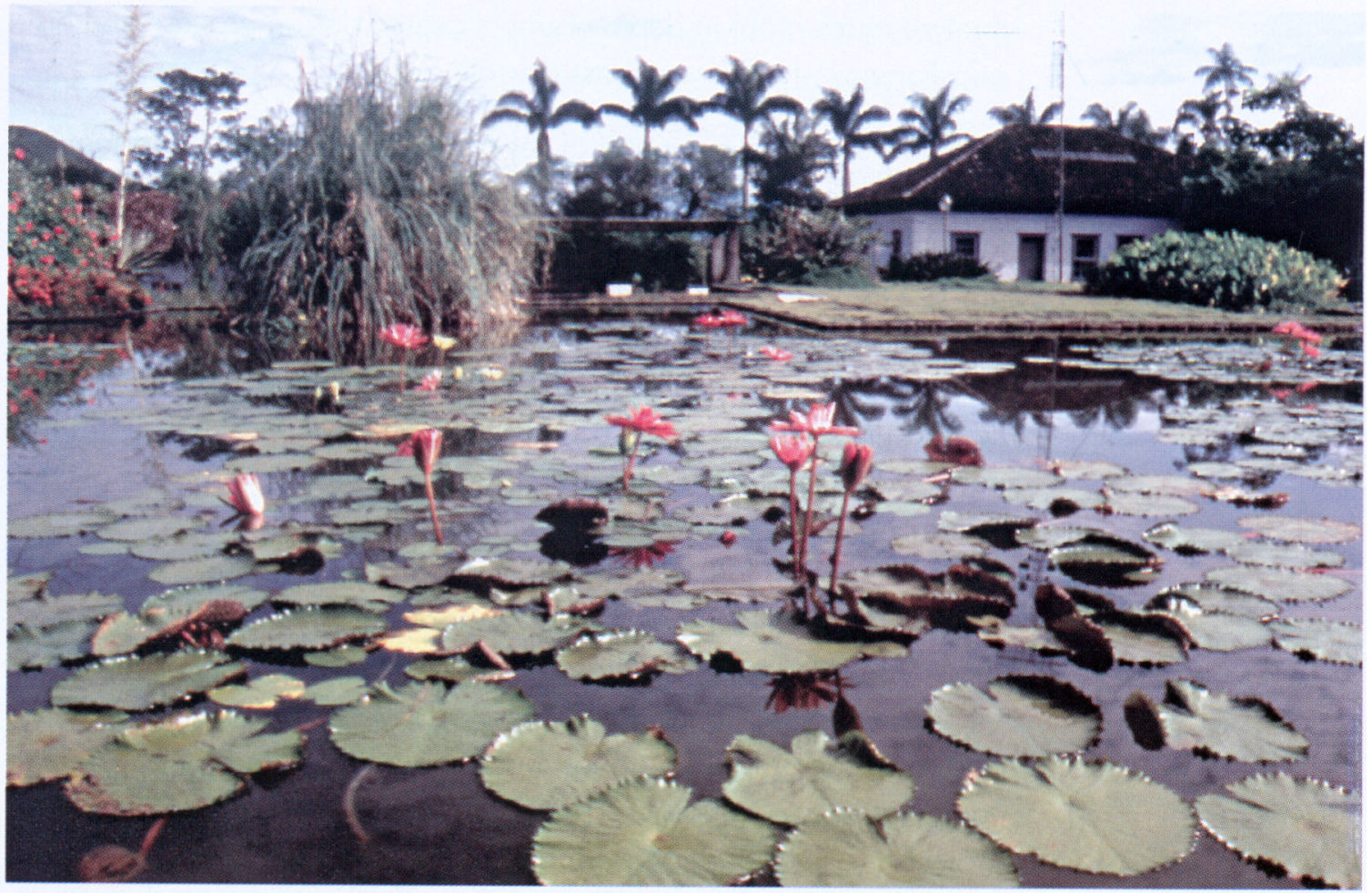

Foto 1 - Fazenda Vargem Grande

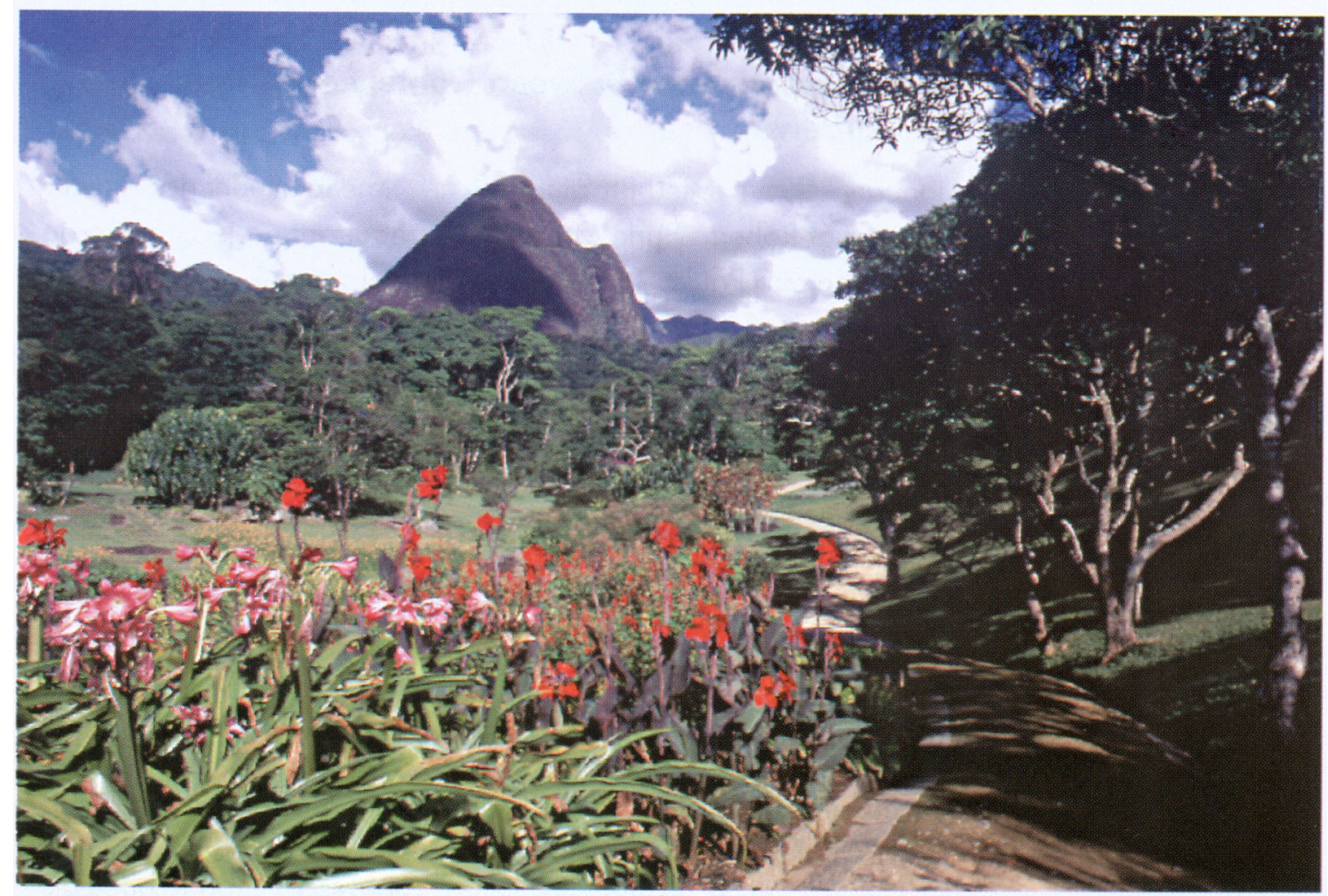

Foto 2 - Fazenda Marambaia

Crédito: Autora 
parks. Fazenda Marambaia is situated in fact in the National Park Serra dos Orgãos, which is part of the Coastal Atlantic Forest ecoregion, while Fazenda Vargem Grande is at the foothills of the National Park of the Serra da Bocaina, which is part of the Interior Atlantic Forest. The Marambaia and Vargem Grande gardens were constructed in phases, and changed gradually under Burle Marx's direction. He revised the original schemes repeatedly, incorporating the feedback of the clients. As for other gardens, the early stage of the design here derived its power from the interesting composition of colors and forms of the ground covers (annual, perennials, and shrubs), an effect that could be achieved immediately. This layout is often the one depicted in Burle Marx's gouaches, which usually described the ground rather than the tree canopy layer. In fact, because few nurseries existed at this time, trees and palms were available to Burle Marx only as seedlings or in very small size less than a meter or half a meter high, and therefore trees initially would read as part of the ground cover or shrub mass. Only after twenty or more years of evolution would the garden acquire volumetric complexity and the three-dimensional connotations it reveals today.

Indeed, when I visited the Marambaia garden, I was surprised by the existence of a diverse and mature canopy, which was not apparent in the drawings and photographs I was familiar with from earlier publications (Figures 3 and 4). This canopy defines today a multilayered space rich of diverse intermingling species, often quite similar to the complexity of the surrounding forest. In fact, many seedlings taking root by chance after natural seed dispersion from the surrounding forest were not removed from the tree masses originally planted, and it is nearly impossible to distinguish today where the garden ends and the secondary forest begins. Thus, this layered space today is a fundamental structure that integrates the garden design with the existing landscape. This fact raises questions on the usefulness of conventional means of representation. Indeed, as I was trying to represent the tree canopy myself in my drawings, it was impossible to convey with circles or other conventional planting symbols the structure, texture and light qualities of what is today a tropical forest. This perhaps explains Burle Marx's lack of interest to simulate in many of his drawings the final or precise conditions of a garden canopy, which is usually a convention in landscape architecture. He preferred instead to show the ground-cover plan, which was easier to depict, control, and predict in the expected forms and composition. 


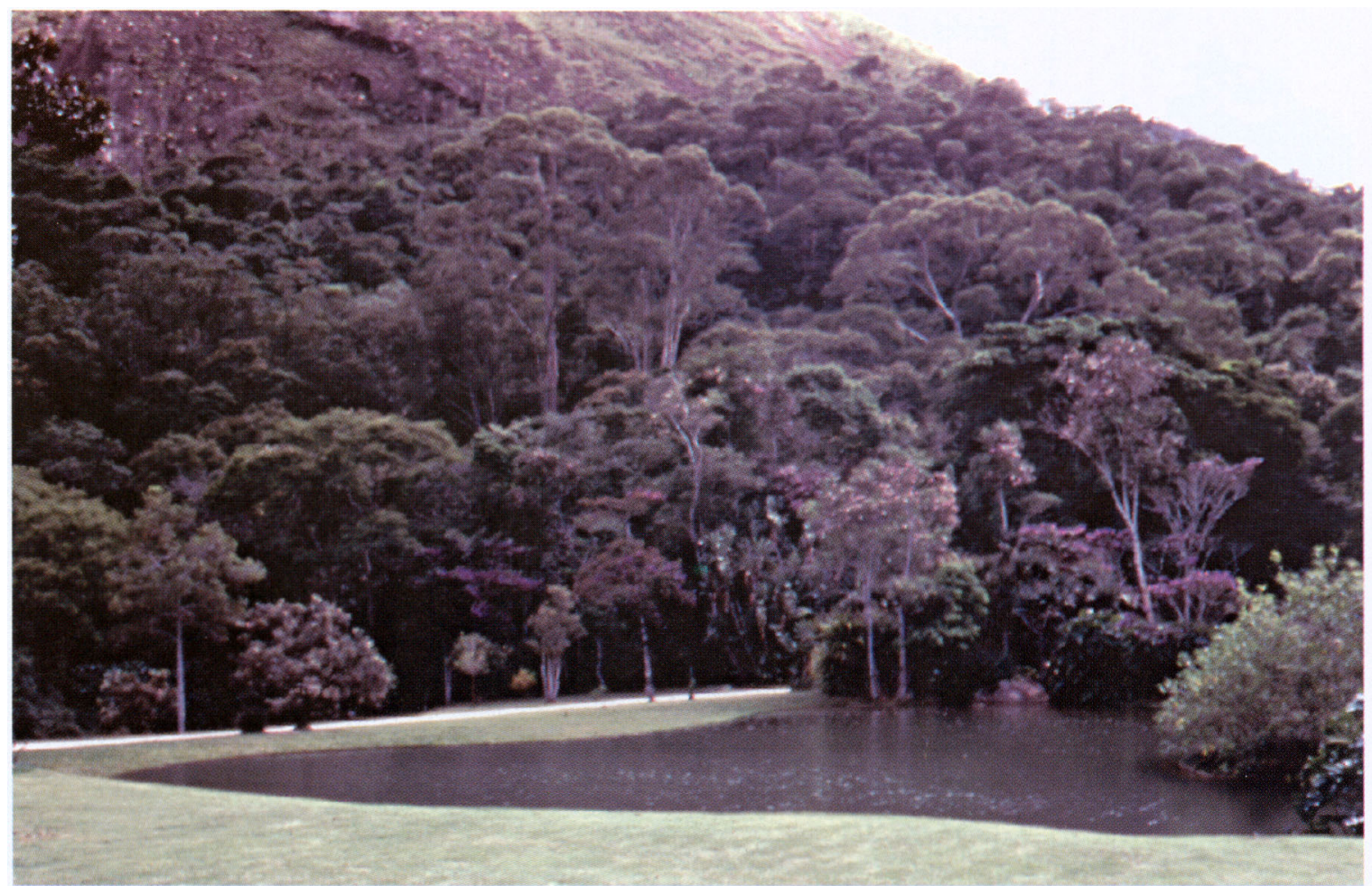

Foto 3 - Fazenda Marambaia

Crédito: Autora

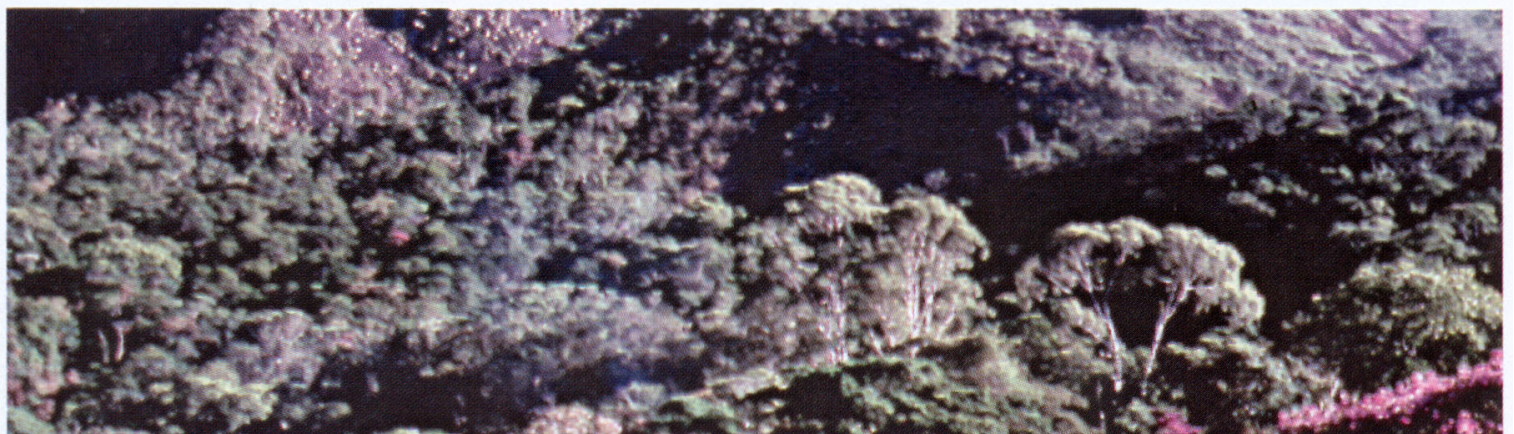

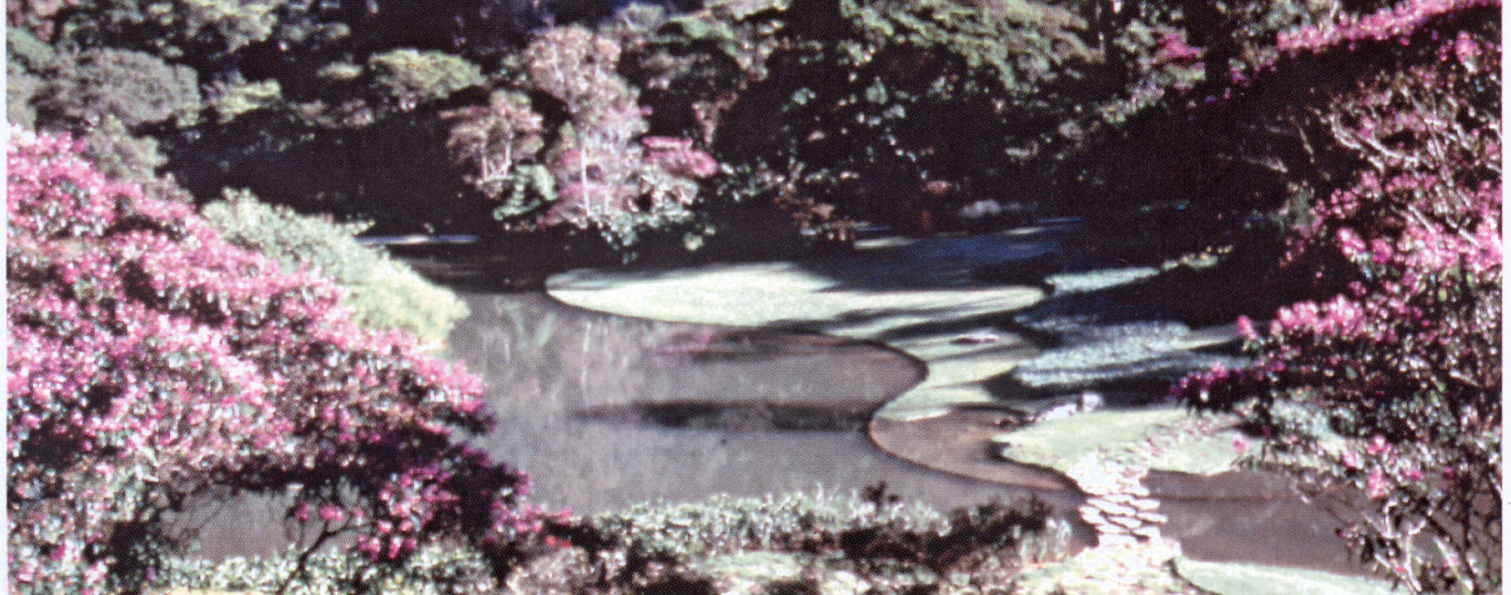

Foto 4 - Fazenda Marambaia

Crédito: Autora 
Drawings, photographs and written texts also rarely have captured the imposing presence of the landscape surrounding the site of Burle Marx's projects, and generally have ignored the elaborate framework of their social or ecological structures. This larger landscape affects deeply the meaning of the garden or park. Whereas in urban parks such as Flamengo the social landscape is a very important structural component in the meaning of its design, in Marambaia and Vargem Grande the landscape of mountains and forest, hills and pasture-land or abandoned coffee fields is the one that has immediate impact on the gardens (Figure 5). This larger landscape is not just scenery or background but a parallel, larger reference that becomes readable and meaningful in the garden detail. In other words, there is a purposeful juxtaposition of two physical and spatial realities - the garden and the environment beyond - and the garden experience becomes the metaphor of the larger, physical or mental image. This is not only obvious in the sensuous landforms that articulate the Marambaia garden, echoed in the shape of the planting beds. It is also apparent in the careful layout of terraces that respect the coffee fazenda terreiros in Vargem Grande, and in the water treatment carried through the garden by gravity, which situate both gardens within a larger system of valleys and relieves. The surrounding context is also expressed in the fact that local rocks and plants indigenous to the site such as certain bromeliads (Vriesia ssp.) and orchids (Cyrtopodium andersonii) (Figure 6) were literally carried down the mountain in order to reconstruct the interaction of plants, soil and rocks in new ways.

Another way to explain this parallel relationship between two scales of landscape is the temporal resonance between the flowering rhythms inside and outside the garden. In Marambaia, for instance, the yellow flowering Cassia trees (Senna spp.) and many species of violet and purple flowering quaresmera trees (Tibouchina spp) are echoing in the garden the complementary contrast of colors to be found in the summer in the surrounding forest. In doing so, Burle Marx intensified a natural phenomenon, making its legibility easier within the garden. He also added interplay of contrasts in other seasons, for instance in winter, using the purple of rhododendrons and the yellow of Tabebuia (ipe) and Bulbine frutescens, and Hemerocallys and Crinum xanthophyllum as ground cover with additional splashes of red areas in the flowering Erythrina trees; during the whole year, except when the canteiros are redone, the contrast between Solelenostemon scutellarioides in yellow-green and reddish-maroon varieties or red Iresine herbstii and grey-silver Helichrysum petiolatum ground covers. I want to stress here that Burle Marx's use of color goes beyond a 


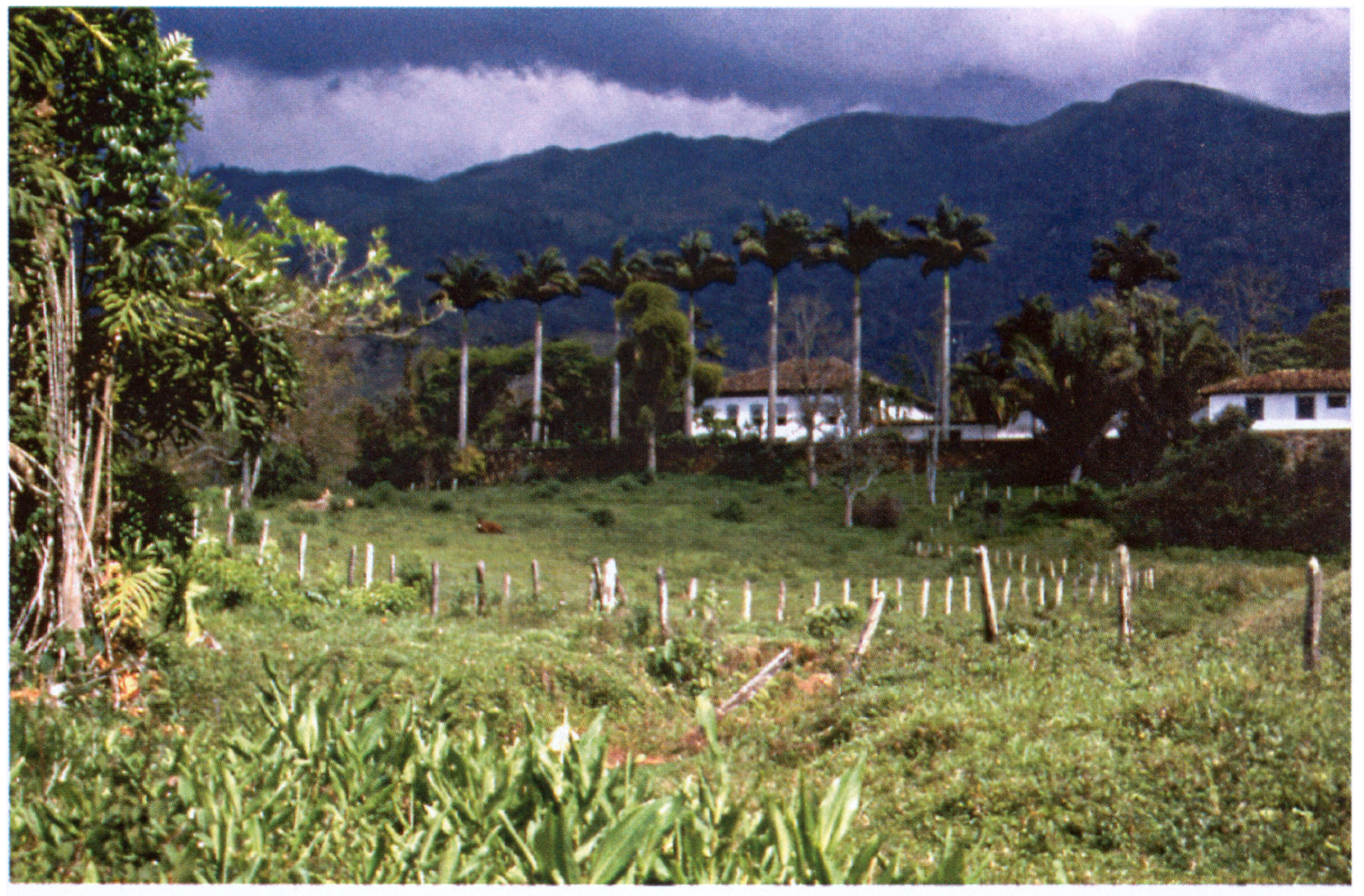

Foto 5 - Fazenda Vargem Grande

Crédito: Autora

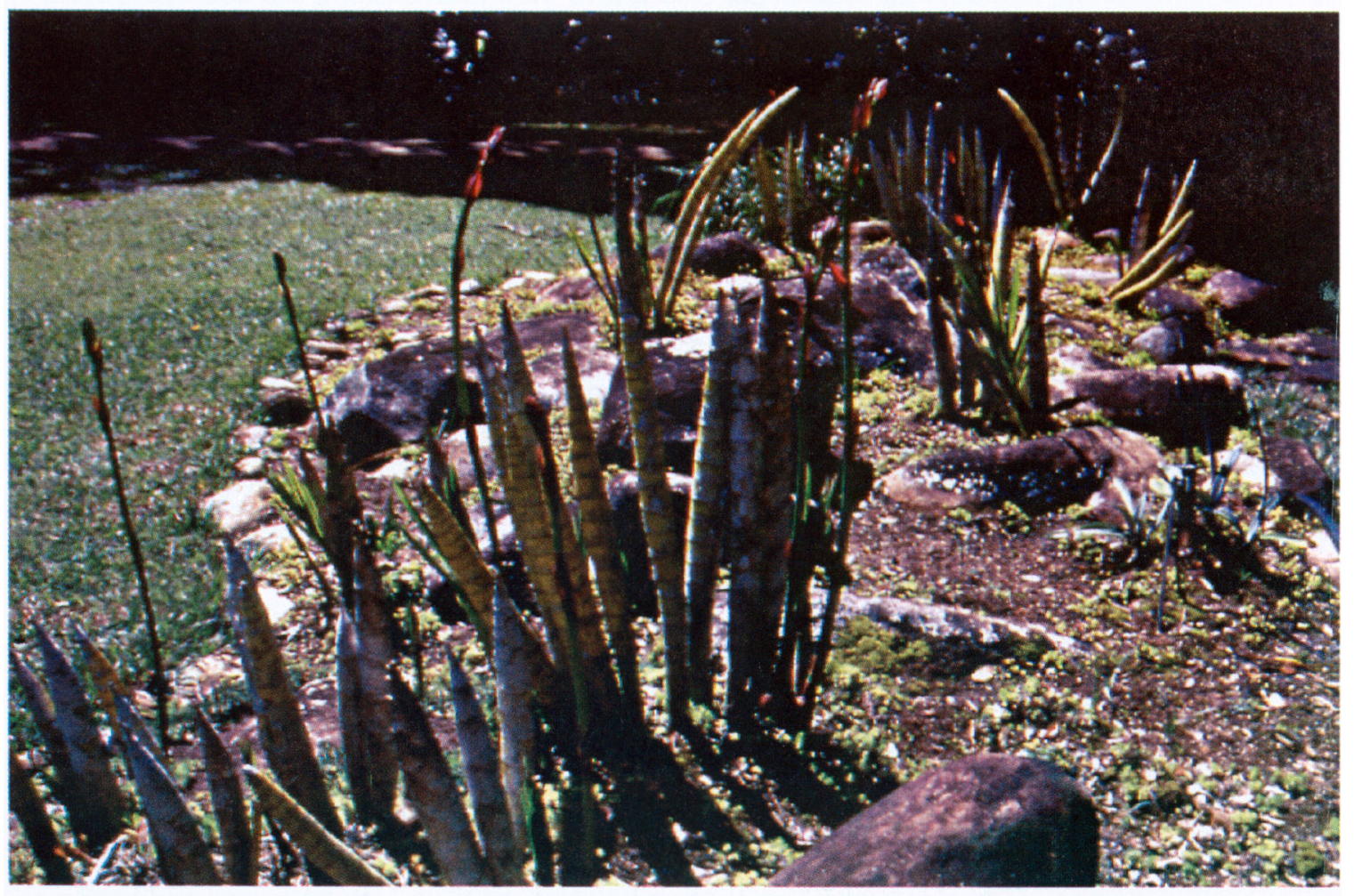

Foto 6 - Cyrtopodium

Crédito: Autora 
painterly, two-dimensional application, even though this aspect is also a component of his work, and this garden from the air in fact truly looks much after a Jean Arp's or Joan Miró's painting (Figures 7 and 8).

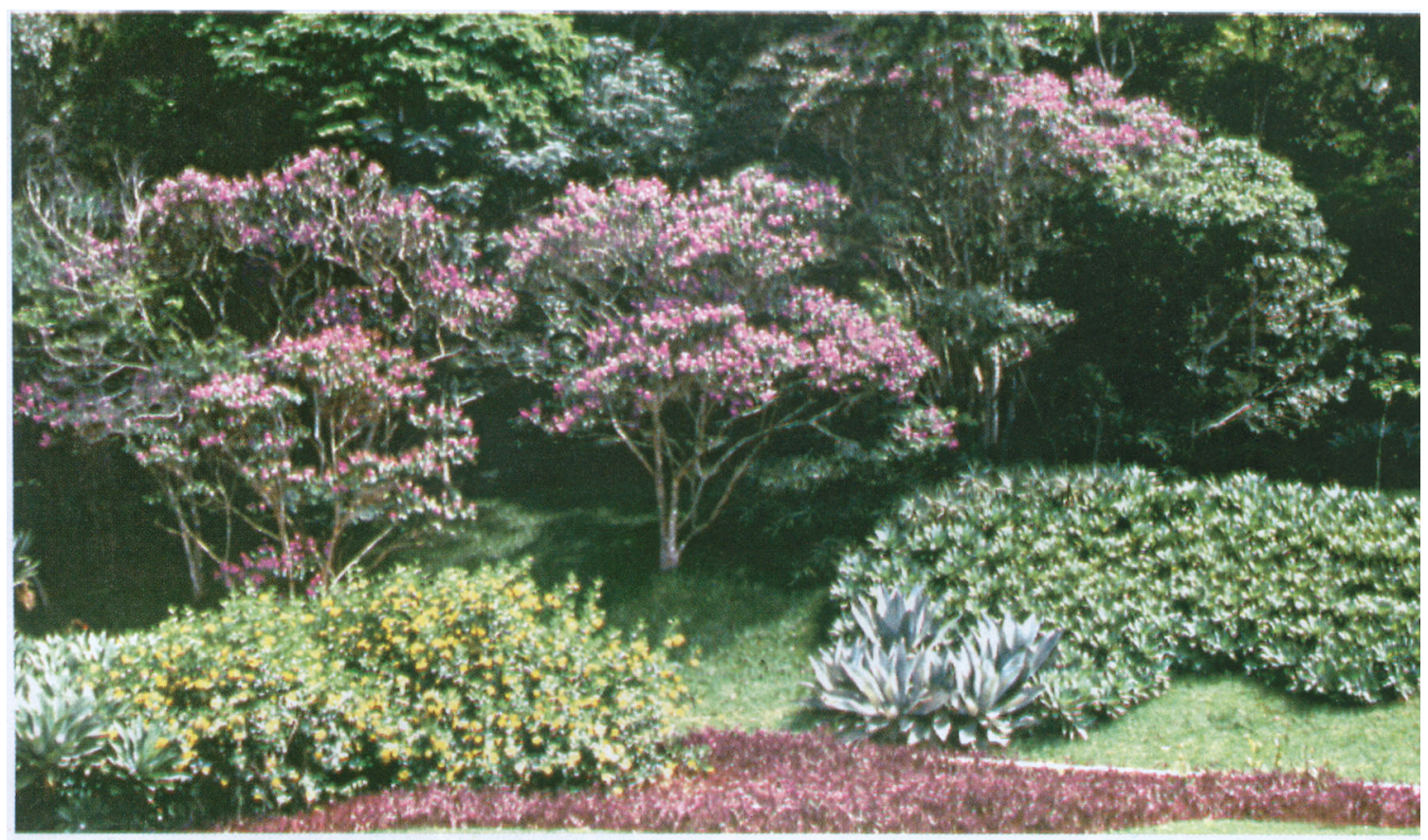

Foto 7 - Fazenda Marambaia

Crédito: Autora

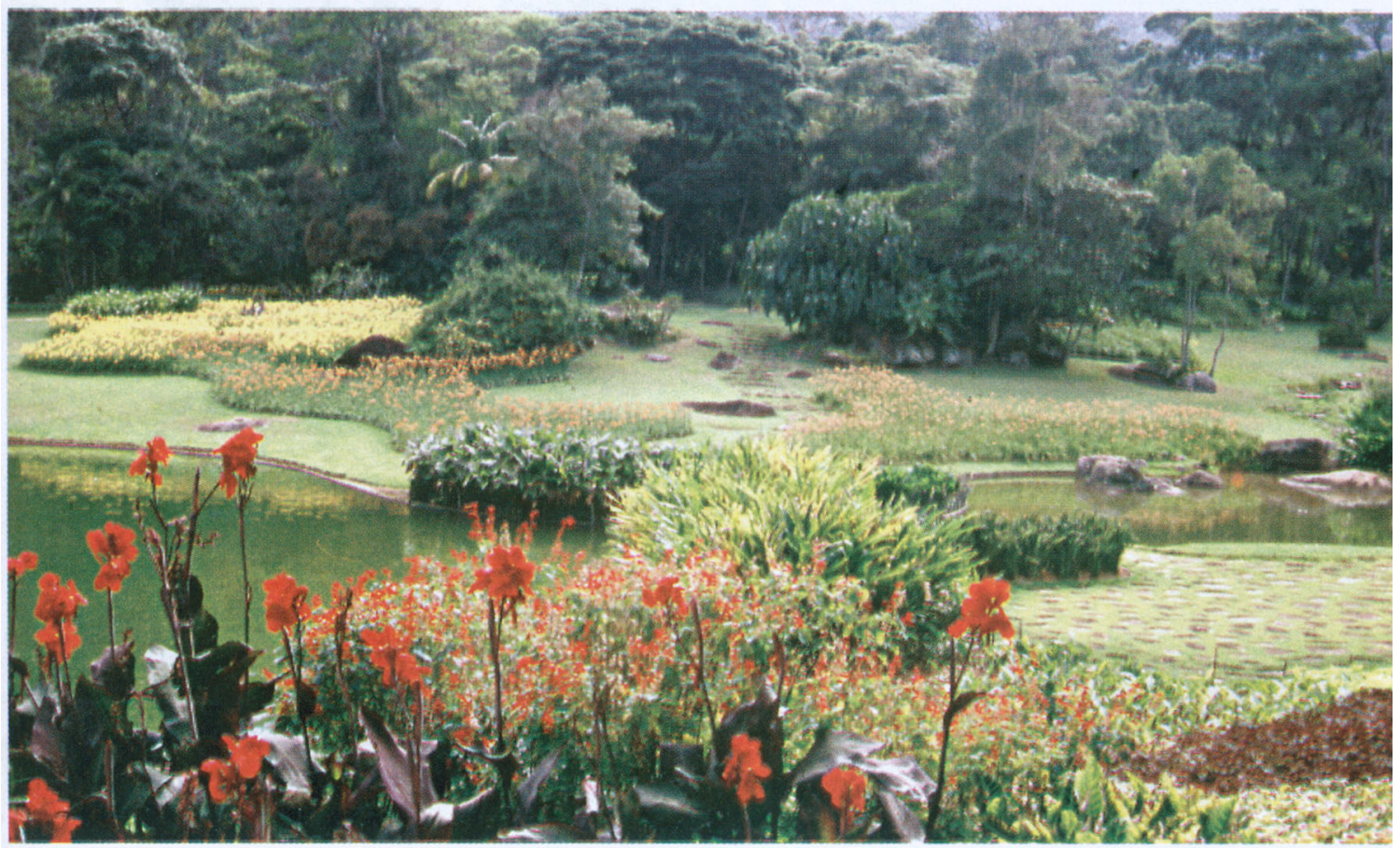

Foto 8 - Fazenda Marambaia

Crédito: Autora 


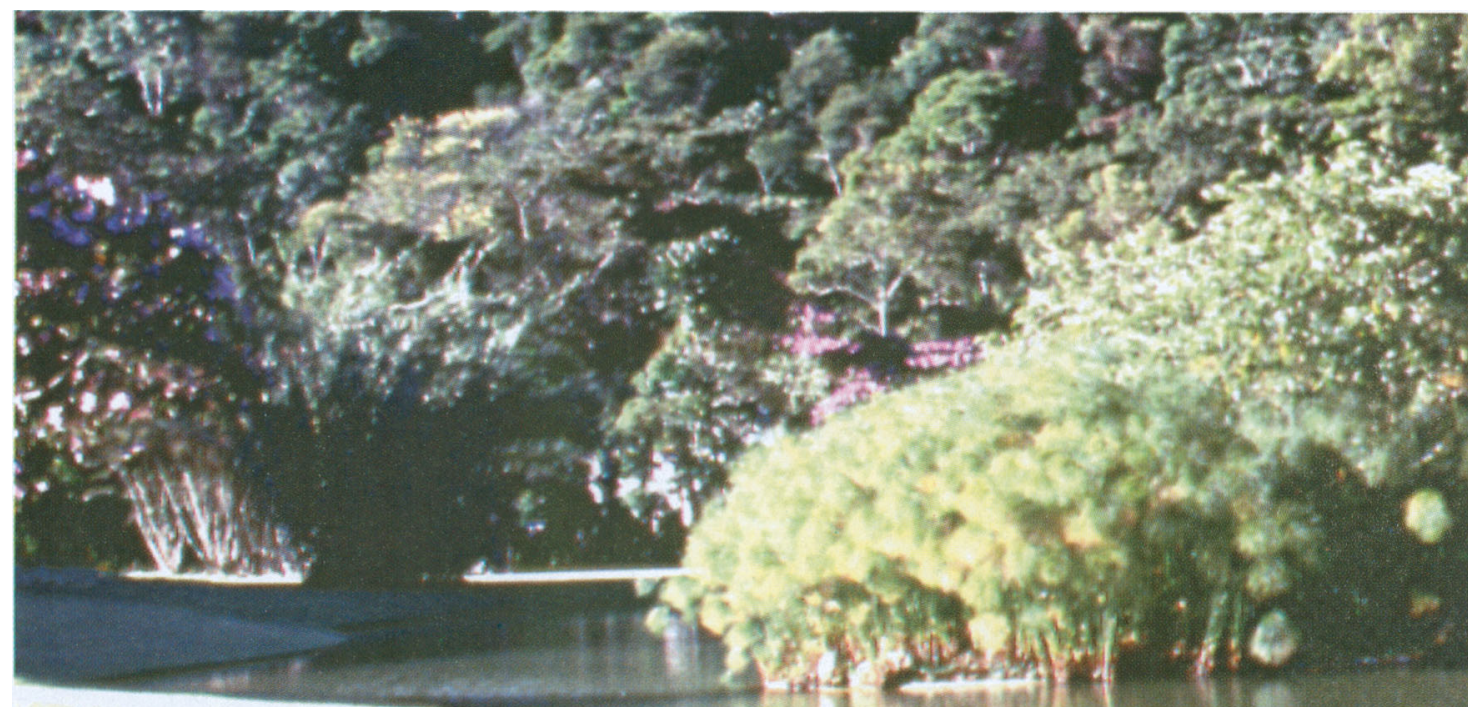

1)

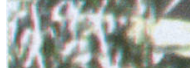

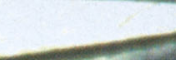

A.

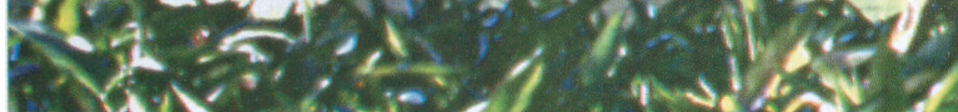

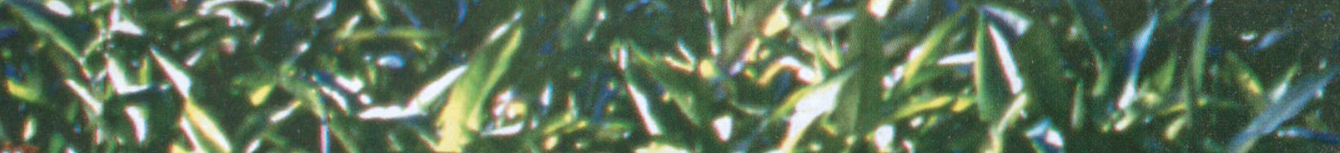

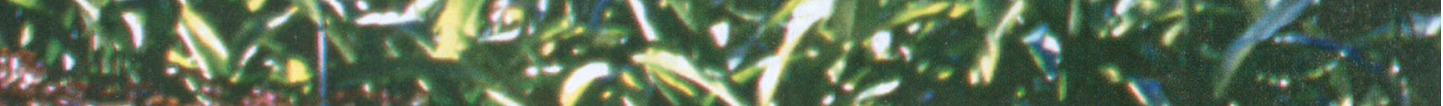

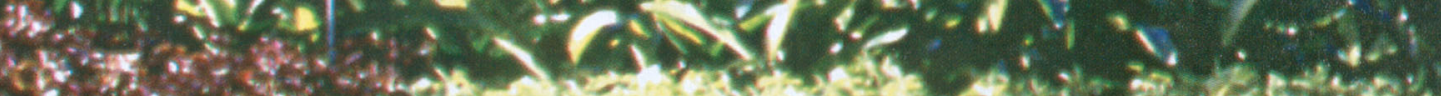

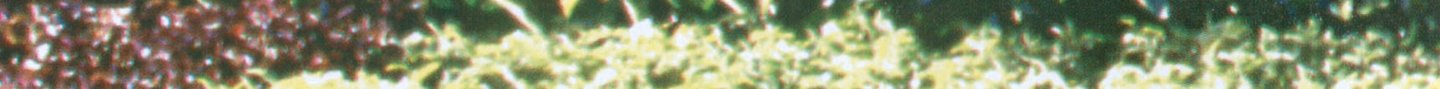

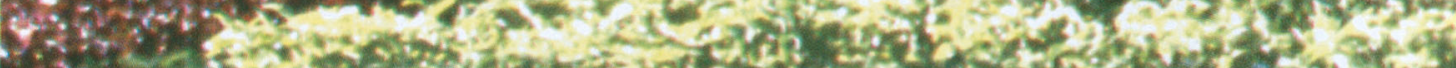

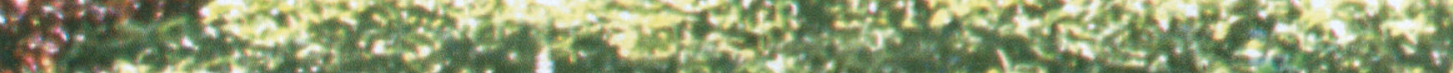

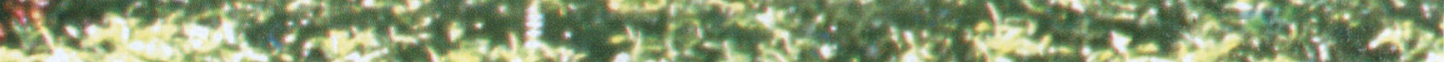

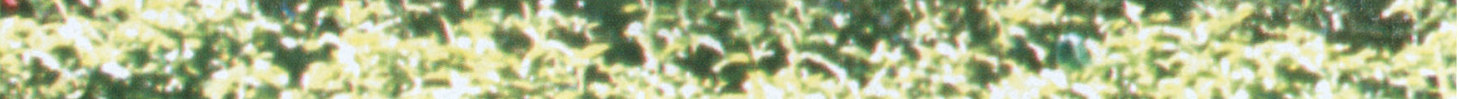

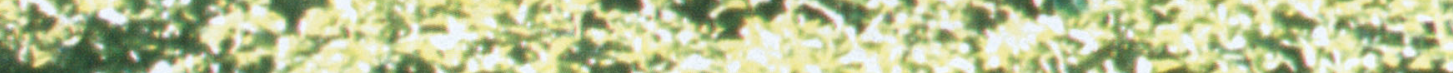

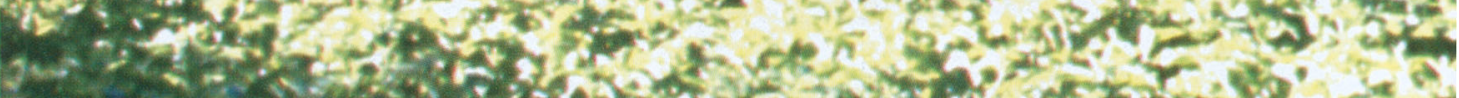

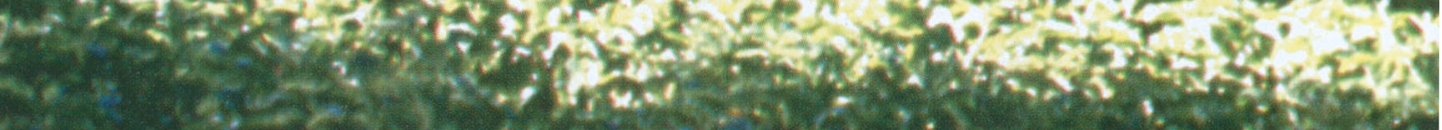

Foto 9-Fazenda Marambaia

Crédito: Autora 


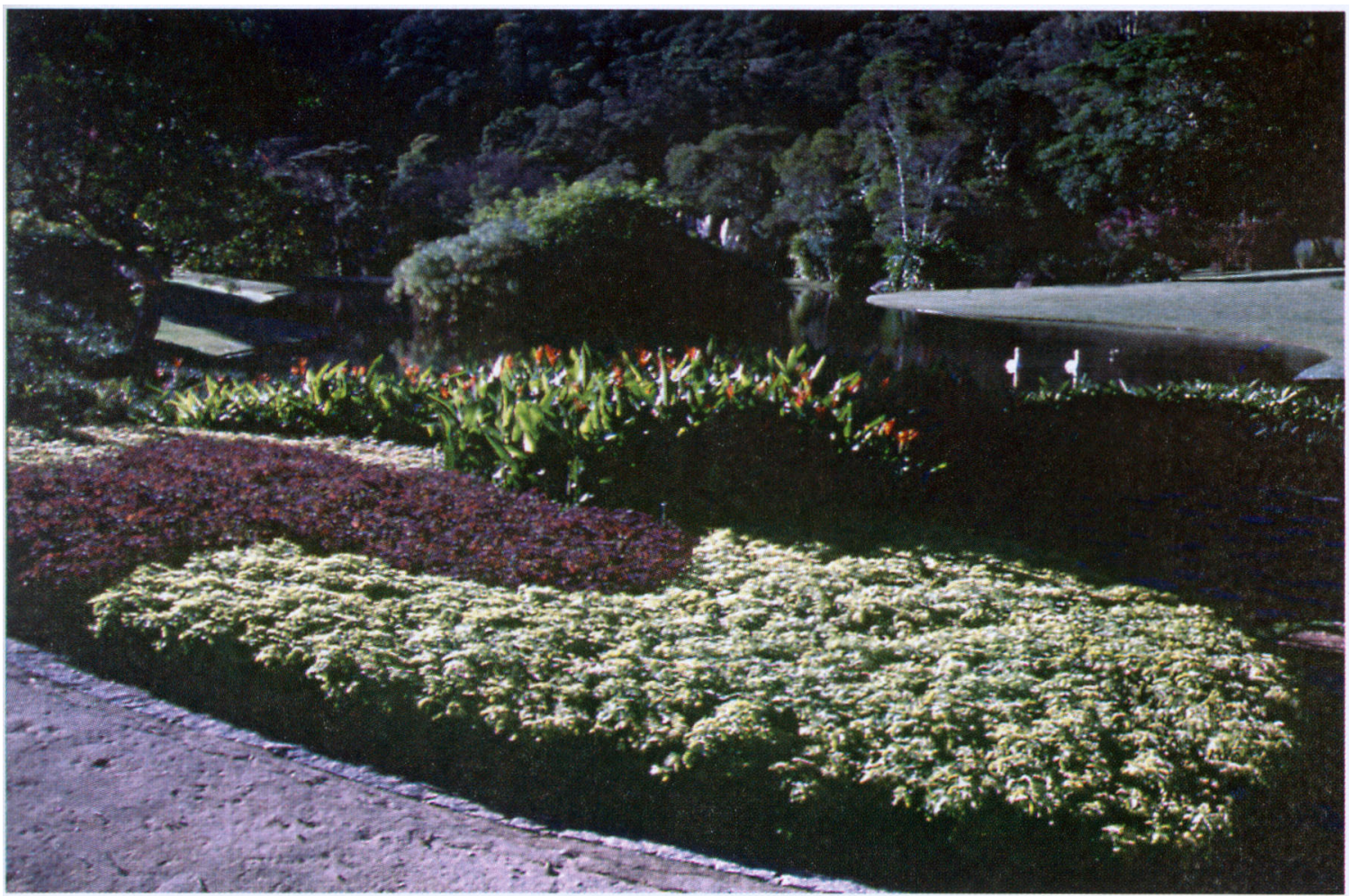

Foto 10 - Fazenda Marambaia

Crédito: Autora

In fact, contrasting hues and intensities of color determine a fragmentation of perspective and increase the complexity of space. These qualities, which I believe characterize the Marambaia garden as a cubist landscape, are due to the phenomenon known in color theory as "afterimage". The afterimage effect increases when contrast is created between a bright or intense hue and a background of dull color, generating complementary colors in the eye that overlap and juxtapose with the existing colors, as is the case in the Serra dos Órgãos nearly every summer afternoon, when bright sun rays pierce clouds and rain while the darkness of shadow increases. The flowering trees - from the dark garden edge, from strategic plant masses begin a dialogue with the bright ground covers in the area of the garden hit by sunrays, and the fragmentation of space thus begins. As light shifts, changing the value or brightness of the plant masses against a simultaneous changing background, the effects of afterimage are accentuated and can be transformed by a sudden change of weather conditions. This logic explains Burle Marx's concentration of bold color swatches precisely in those areas washed with light at sunset, or in strategic positions along the path (Figures 9 and 10). Therefore, they are fundamental to articulate dynamically an otherwise predominantly dull or dark composition. 
It is important to stress also that the careful placement of plant color and texture not only affect movement, volumes, and visual perception, but is also a way to capture and emphasize the shifting qualities of light and weather, which are so powerful in Brazil comparing to temperate climates. In other words, they make the phenomenon of light powerfully present. This is quite clear in Vargem Grande. Color contrasts here has an equal role in continuously changing perceived depth and perspective through the seasons, even if more subdued in the interplay of tints of opposite blues and oranges, or yellows in other months with small amounts of reds. Patches of color in fact shift location across the site with the flowering season, and it is amazing how calculated that color balance re-occur in different areas in different months. Every single day, from early morning to early evening there is a sequence of shifting foregrounds and backgrounds, focal points, and horizon lines, which erase the two-dimensional formality of the plan and affect the tree-dimensional experience of the garden space. For instance, the Licuala palms leaves and Aechmea blanchetiana leaves light up like fire when touched by late afternoon sun and suddenly become a foreground feature in the Garden of Volumes. This temporarily altered value contrast also occur in the Water Garden, where the flower tips of Belacamda chinensis in January or the inflorescences of Cordateria selloana in August establish an ephemeral relationship between solid and voids (Figures 11 and 12).

Layered canopy mass, cross-over relation with the surrounding environment, and fragmentation of perspective and volumes with shifting colors during the seasons and weather change, as I described above, are three among other key spatial characteristics of the Marabaia and Vargem Grande gardens. For me, these became fundamentals in the list of essential concepts behind the design and the experience of the two gardens. I believe these are as important to preserve as a particular shape of a planting bed, or the specific plant species used in the garden. I also emphasized today the instability and ephemeral connotations of these spatial qualities, and thus the inability to record them in conventional drawings. Spatial qualities such as these cannot be discovered and analyzed without a personal experience in, and a deep knowledge of, site, seasons and context.

What are the implications of the above observations for preservation and maintenance? Once a research intuition is tested and developed scholarly, becoming a set of articulated qualities or conceptual ideas that inform the design, it is possible to devise programs of maintenance that improve those essential qualities in time, rather than fixing them in 


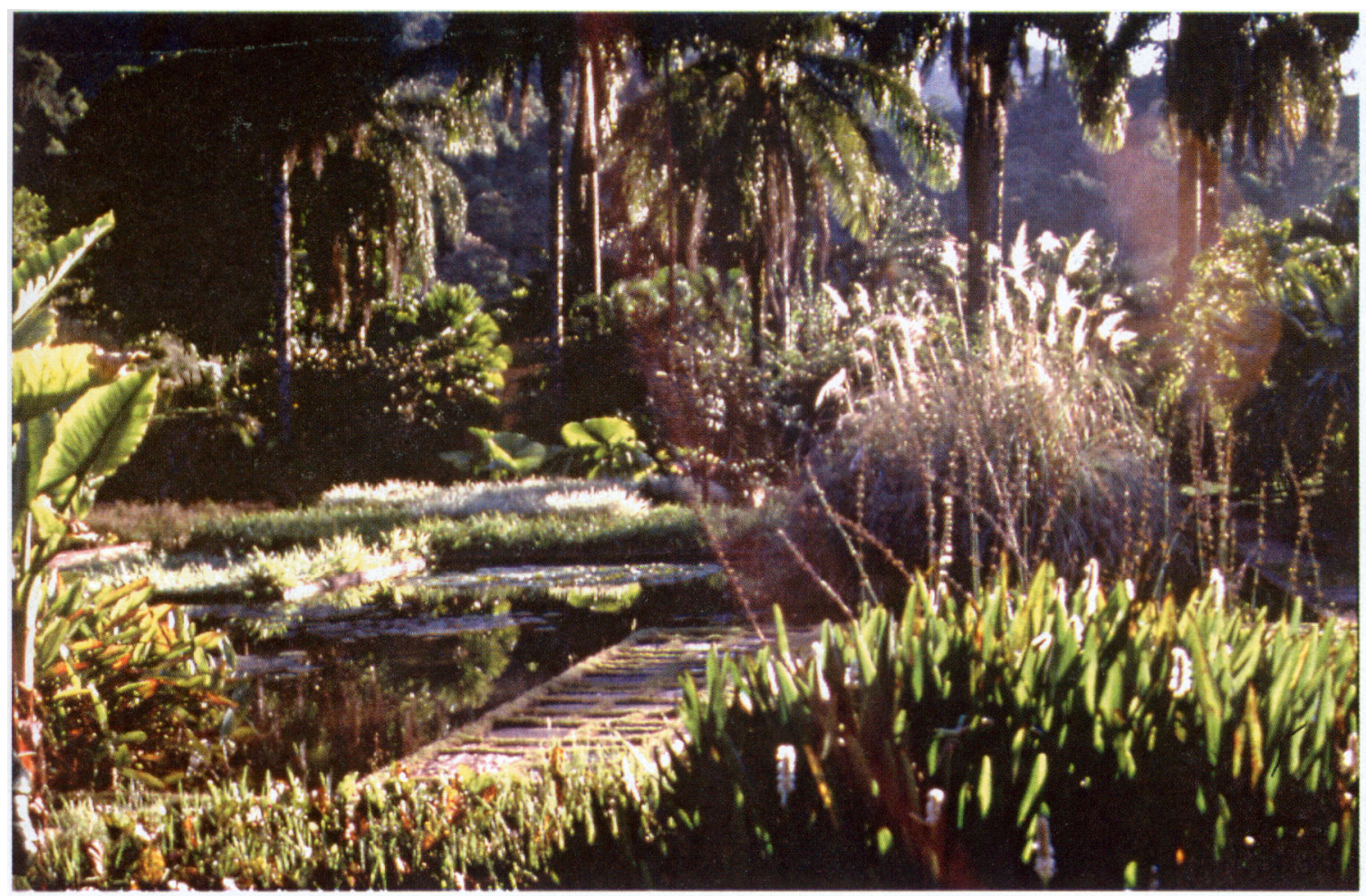

Foto 17 - Fazenda Vargem Grande

Crédito: Autora

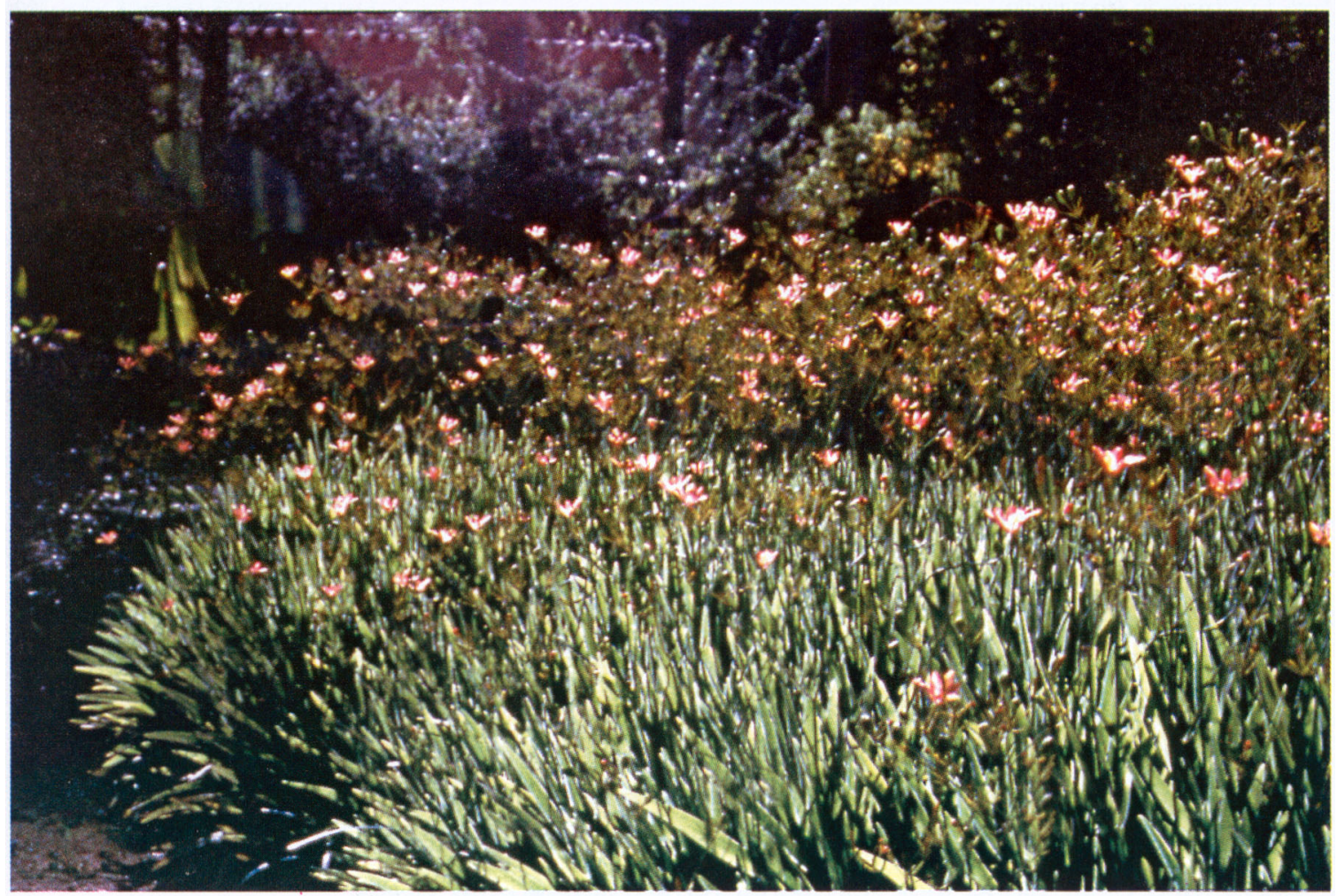

Foto 12 - Fazenda Vargem Grande

Crédito: Autora 


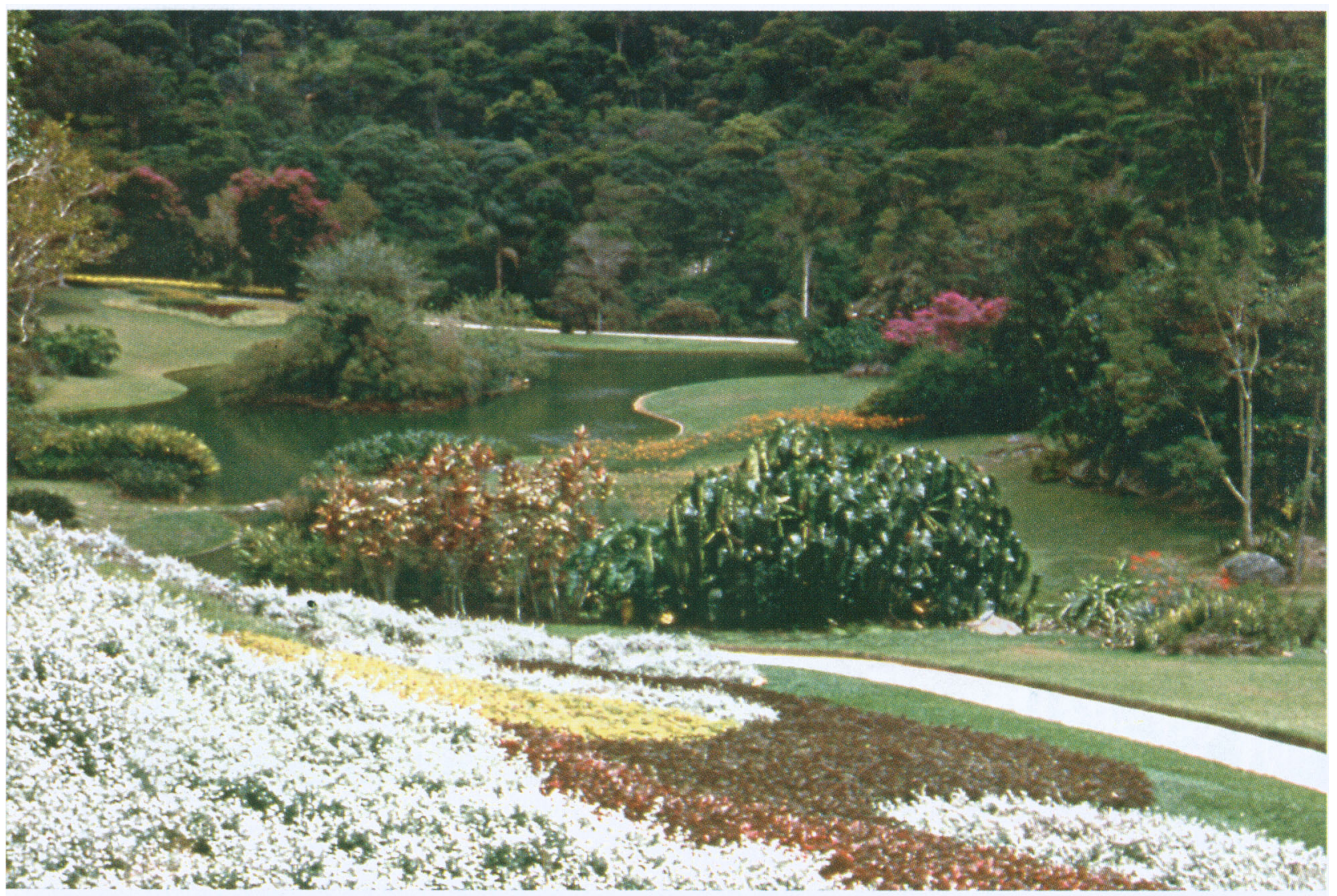

Foto 13 - Fazenda Marambaia

Crédito: Autora

history or, worse, destroying their intrinsic nature before they are truly understood. The past condition in a landscape is not necessarily the best to preserve, and often a landscape needs the designer to spend years of working with it, to refine an idea that was only rudimentary at its construction, molding and refining the landscape as it grows to its maturity. For instance, I believe that the Monteiro garden has improved in the last 10 years, having got rid of many herbaceous plants that were cluttering the strong basic color scheme, while gaining in structural complexity from a well kept and mature canopy layer (Figure 13). I also believe that the Garden of Volume in Vargem Grande is potentially more interesting today in its neglect, because the original scheme has not been deliberately changed by a designer but has changed on its own through the instability intrinsic in the processes of organic life. This 24 offers unique opportunities for working out a new, more beautiful scheme from the spontaneous multiplication of bromeliads, orchids, agave and other plants that, left alone, have colonized the stones 


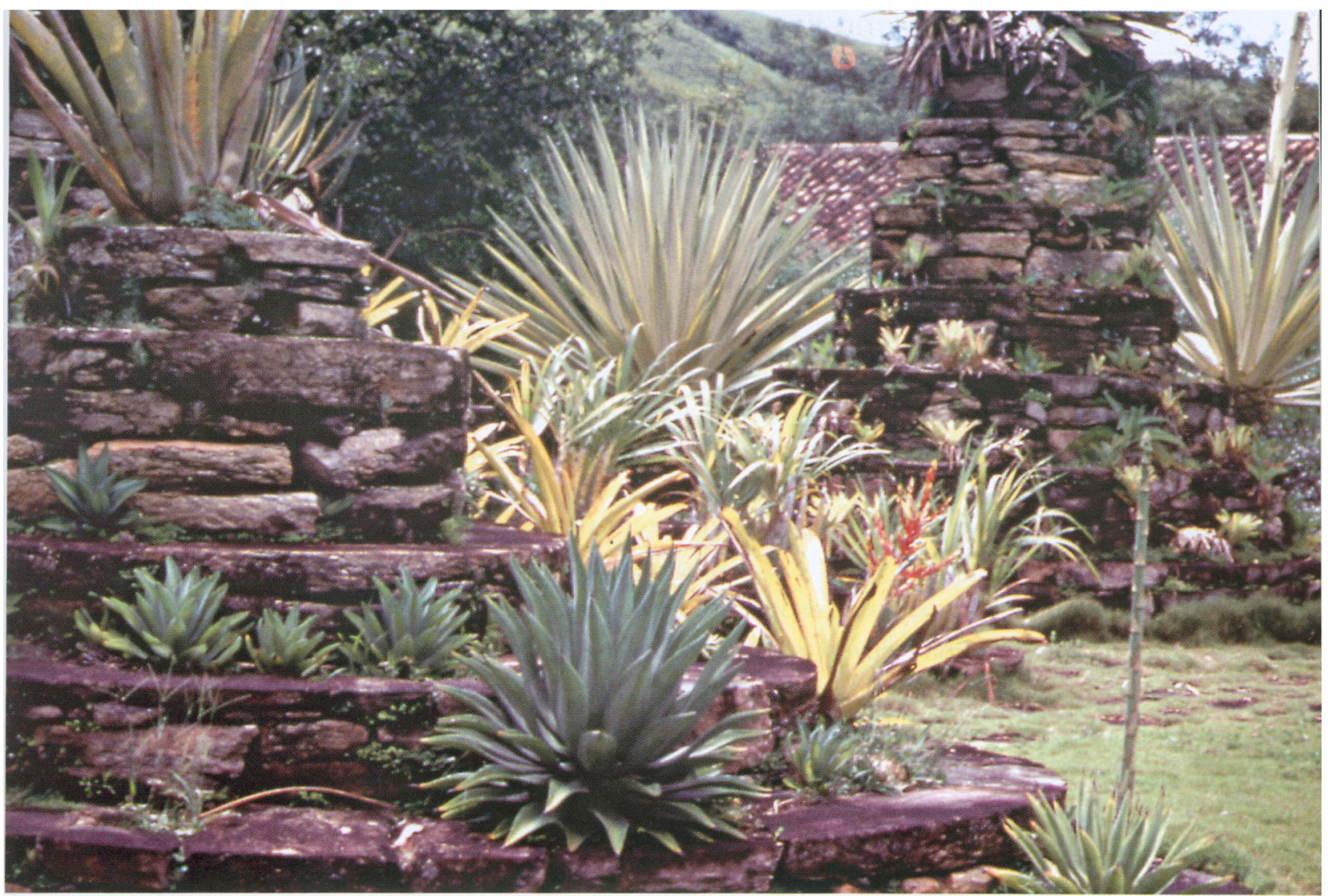

Foto 14 - Fazenda Vargem Grande

Crédito: Autora

overtime (Figure 14). Burle Marx would be trilled to start once again the composition of the garden of volume working forward with what is there right now, rather than backward from an earlier drawing. If he was asked to restore the garden today, he would never use precisely the same plants he used in the same location or proportion as before, but he would take advantage and incorporate the unpredictable events that have accumulated over time, perfecting earlier ideas by editing the new material now available, with results probably more complex and refined than the earlier scheme. But here is the key problem. Obviously, we, landscape historians, scholars and practitioners, have the important mission to understand, cultivate and demand for the legacy of Burle Marx to be carried in the future, if we are talking about preservation of his work in authenticity. The question is however, how can we carry on the sensitivity and vision for a preservation program that is able to include also evolution and change in the same way Burle Marx would have done, had he been alive? 


\section{Parque Flamengo and Parque del Este: The Preservation of Conceptual Ideas}

Parque Flamengo, in Rio (1959-63), and Parque del Este in Caracas, Venezuela (1957-1963) remain among the major urban green areas realized in Latin America in the $20^{\text {th }}$ century. I will bypass the important social agendas that inspired both projects and focus only on those peculiar aspects of their design that represent a synthesis of Burle Marx's conception of the park in its relationship to nature, perhaps because this aspect is more difficult to interpret and preserve. I am going to illustrate seven aspects that I believe are among the most important to study in depth to this regard.

First, Burle Marx created complex plant compositions - what he called "artificial ecological associations" - where exotic plants from different tropical countries would find expression in many possible permutations among the Brazilian natives, regardless of their original genotype or taxonomy. If their morphology or physical characteristics (phenotype) could be integrated visually and artistically to their advantage, the overall ecological distortion would not be, for him, so to speak, a sin (Figures 15 and 16). Even if Burle Marx gave priority to native plants,

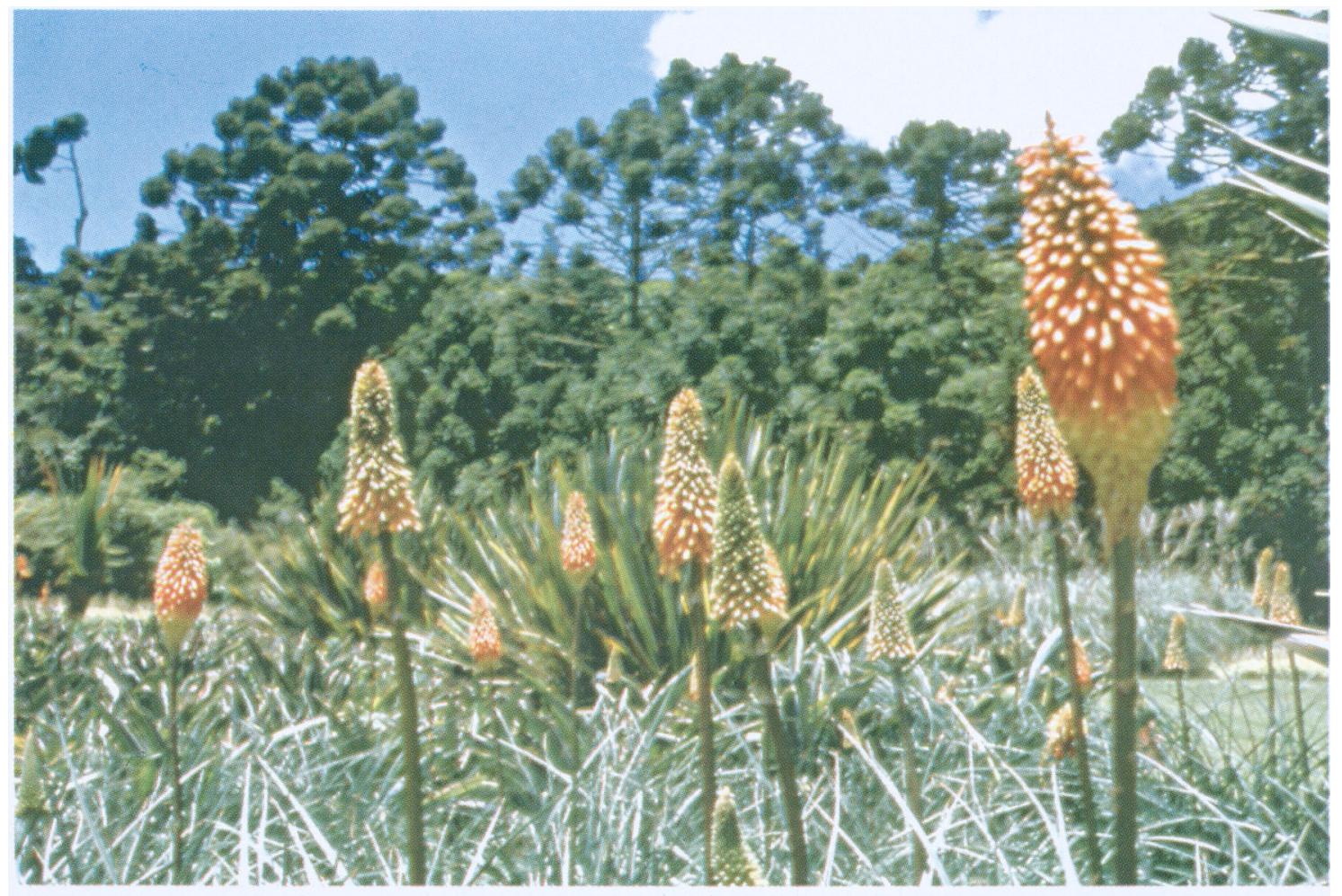

Foto 15 - Garden of Ralph Camargo, Petrópolis

Crédito: Autora

Paisagem Ambiente: ensaios - n. 16 - São Paulo - p. 9 - 41 - 2002 
nature for him was always a pre-text, a point of departure. Plants found elsewhere under similar climatic and pedological conditions would always find a place with their "fellow" natives, and thus contribute to the creation of strikingly new, contrasting associations. Artificial ecological associations are to be found in all his projects, not only in these two parks. While in Parque del Este, Burle Marx used an existing forest to shelter the growth of a whole new community of native and non-native species in Flamengo he adopted an empty landfill exposed to seasonal salty winds to test the pioneering and adaptative capacities of a wide range of trees and palms growing in nature in the most adverse conditions. Both parks remain today a successful ecological experiment, and an incredible "botanical garden," but of a unique kind. Here, unusual species are recognizable not from a label on the ground, but from their distinction, in terms of relative placement and massing.

This brings me to the second point. As it is well known, the trademark of Burle Marx was to cluster in large numbers plants of the same species. The conceptual idea behind this was that the multiplication of one plant in a large group of the same species would magnify its characteristic form or intrinsic beauty, making it easier for people to

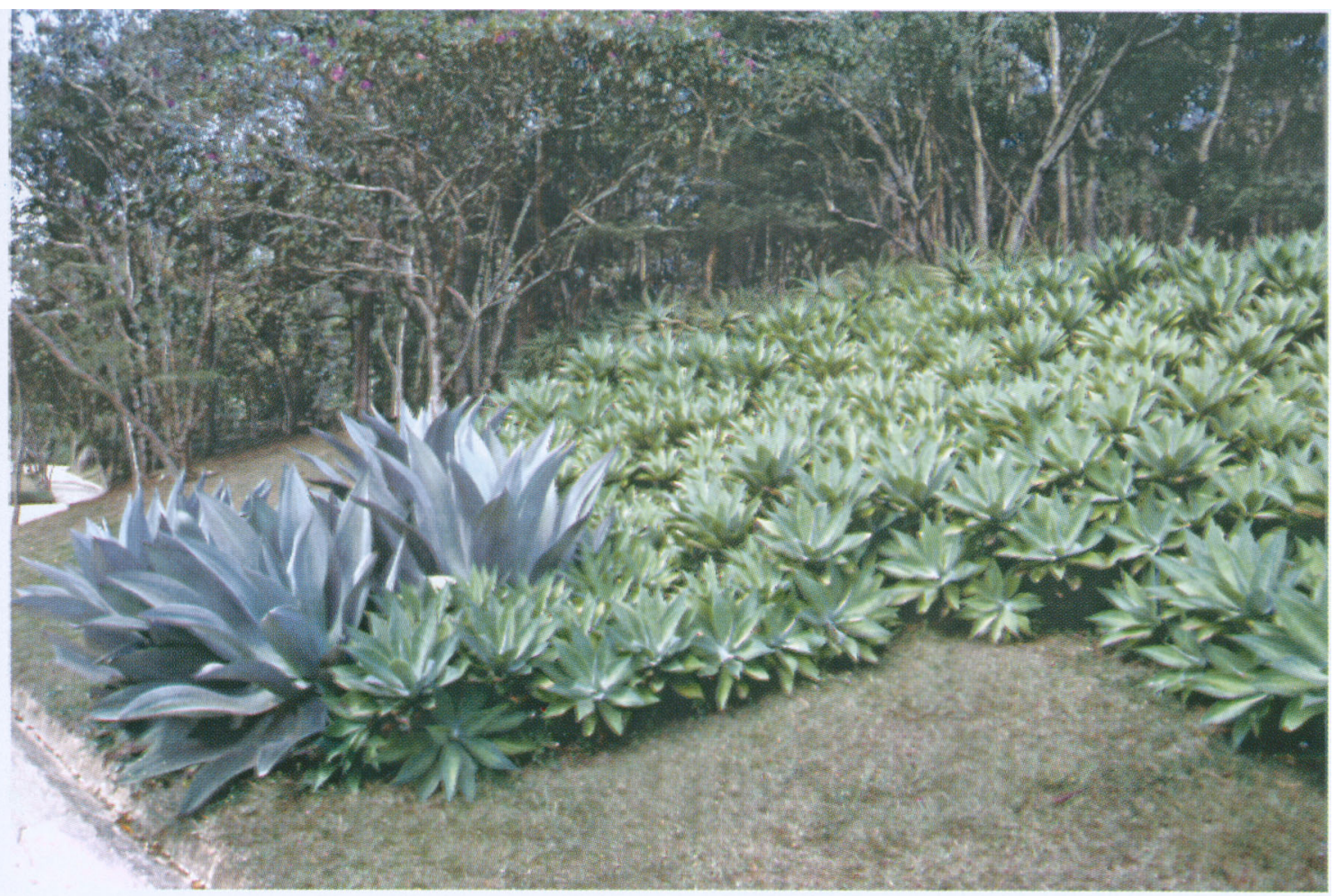

Foto 16 - Fazenda Marambaia

Crédito: Autora 
notice it and emotionally appreciate. Burle Marx believed that the collection, identification, propagation, and re-composition of the Brazilian flora in urban parks in such large masses and such striking compositions would in the end help turn the wilderness of the feared Mata, Brazil's endangered environment, into an intimate experience that everybody could understand, value, and therefore eventually protect (Figures 17 and 18).

Therefore, a more direct and abbreviated relationship with nature could be established in the park, one that would exemplify the elementary play of natural forces in a more human and less threatening environment. In other words, by transforming the textures and colors of the forest into comprehensible, human-scale experiences that elicit an emotional response from the park visitor, he was hoping to educate the masses by the thousands, and to confer what Bardi has called an "urban dimension" to Brazilian nature. This would be a means to perpetuate nature in an increasingly urbanized world.

The clustering of large masses of trees and palms in the Aterro do Flamengo has other functions, and include legibility and visual impact for those who experience the park by driving at relatively high speed along the park-way. The tree masses also create an important rhythm and articulation of solids and voids in an otherwise homogenous horizon. In Parque

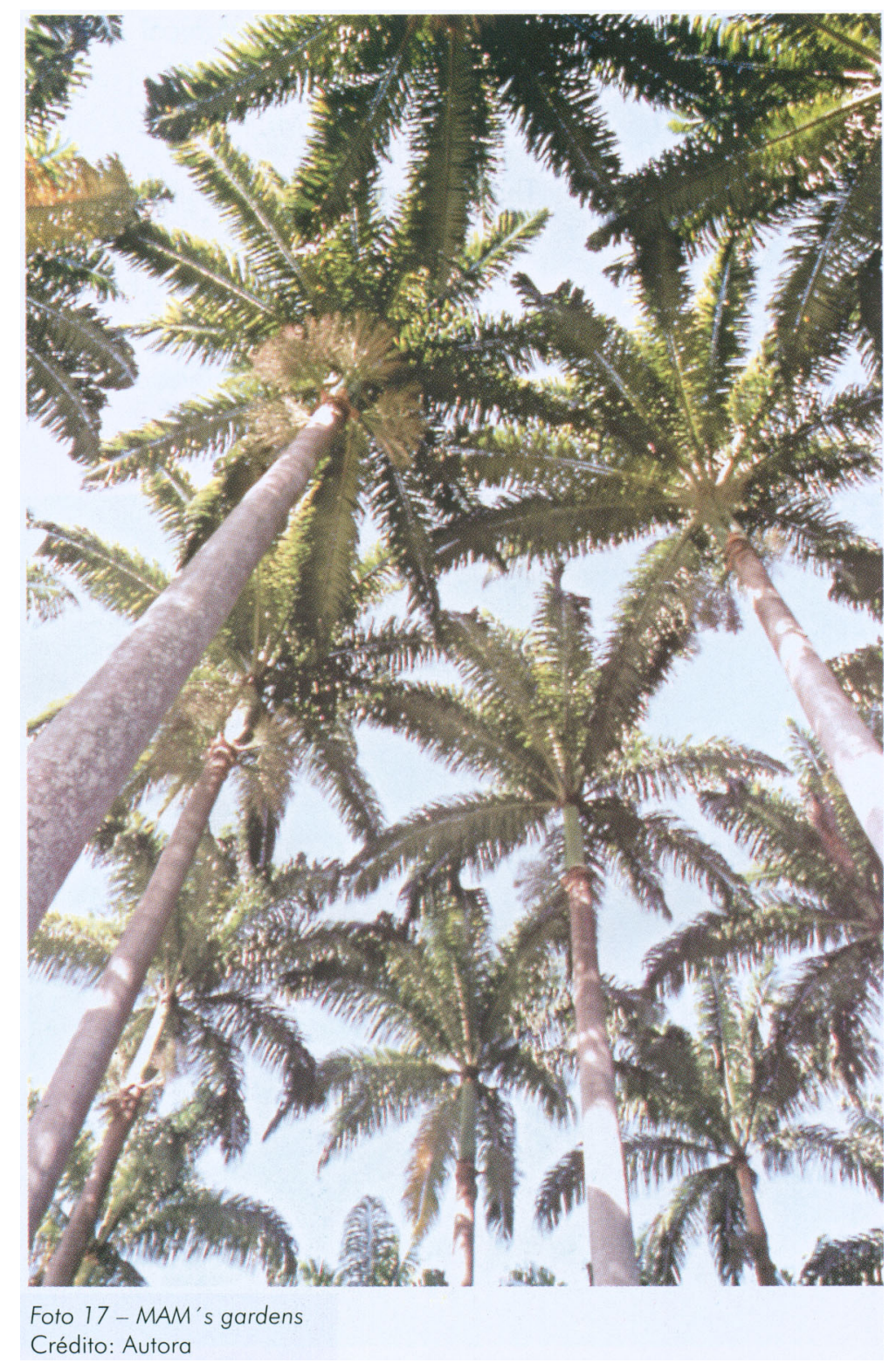


del Este the situation was not the same, as half of the park was created using an existing forest, thus native trees were often planted in small numbers to integrate an already existing canopy. Moreover, Parque del Este does not afford ocean views as Flamengo does: the trees in that park often, rather than framing good view, create an effective screening of the middle-ground horizon of the city cluttered with tall building of dubious architecture. I want to stress in conclusion of my second point, that the careful articulation of plant masses and voids or view corridors, accomplished by distinctive large clusters that interplay with the topography and landforms that were artificially created, as well as the careful spacing among the trees and the groups with each others, are in my opinion the essential idea driving the planting scheme of the Aterro. The preservation of this rhytmical alternation of volumes and spaces is more critical to my opinion than the preservation of single existing specie in the evolution of the park. What die or needs to be replanted is certainly important, but it is equally if not more important the preservation of the overall design concept. And I know this aspect is well known and has been incorporated in the new reconstrutction plan.
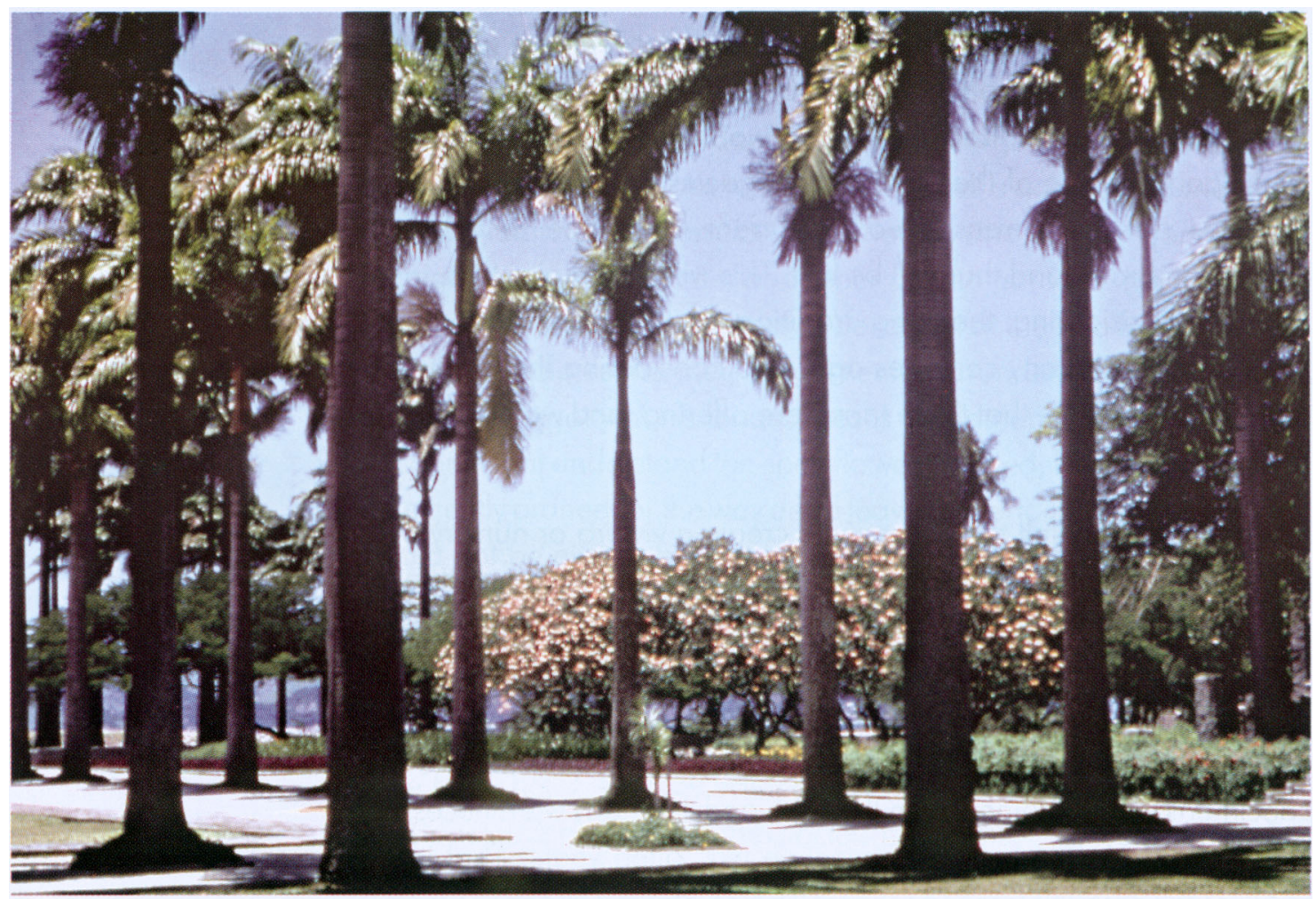

Foto 18 - MAM's gardens

Crédito: Autora 
Third, Burle Marx would rarely engage an important project in a new region or country without first exploring directly the key natural habitats. These excursions became a fundamental component of his design process. They were, as Haruyoshi Ono has stated, an "idea always in the air." They were not only a direct source of autochthonous species: they also allowed Burle Marx to observe in loco and get inspired by the structure and visual richness of a variety or tropical regions, and to understand their dominant morphology, and ecological associations. These were well organized, scientific expeditions, funded through the design fee of a project (as happened in both Parque Flamengo and Parque del Este) or by various sponsoring activities. They lasted one or two weeks according to the itinerary, and saw the participation of a multidisciplinary team - usually a congregation of naturalists, botanists, gardeners, architects and other staff from his office.

The learning opportunity was reciprocal. In fact, on the one hand, the partnership with botanists or plant lovers frequently extended to commissions or collaborations in garden projects. On the other, Burle Marx would transmit his aesthetic appreciation and design talents to his travel companions, and nearly all the architects, botanists and naturalists who shared these experiences with him started designing gardens of their own. The direct connection between the landscape project and the excursion in the natural environment, and the benefits that these well organized excursions would be derived for all the participants, is one of the Burle Marx legacies and conceptual ideas that has not been transmitted to current landscape architectural practice in Brazil, and thus will be lost. This will be a major loss, in my opinion, considering the long tradition of botanical explorations started in Brazil many centuries ago, and considering the invaluable learning experience that these trips were offering, and would still offer today.

Forth, Burle Marx felt the necessity to create a viveiro or nursery area within the park, both during constructing and after its completion, to insure the continuous supply of otherwise difficult-to-find plants. This was a place where the coletas or live material collected from the excursions would be acclimatized and kept under observation for several months, before transplanting on site. If only seeds or one-two specimens were obtained from the wild, and if a many were necessary in the design instead, the waiting time was often years. That is the reason why Parque Flamengo was still being planted fifteen years after its inauguration. And is also the reason why Parque del Este lost gradually a huge number of plants from its original collections as the 
viveiro closed and was abandoned. The viveiro would be a place under direct supervision of the botanist collaborating in the project, and would become a laboratory for training workers and maintenance staff on how to propagate, cultivate and care for the plants of the park. Unfortunately, in Brazil and Venezuela political changes directly affect policy. In the case of the viveiro, this implied discontinuity of planning and management of park personnel a few years after the park was open. Today, no effort is made in restoring the viveiro to its original and important function. In my opinion, the viveiro is a fundamental component of the design concept of both parks, one that allows the intended evolution and didactical purpose of the park in time. Cultivation is a form of preservation, has said Fernando Chacel the other day: the viveiro and its didactic role in the sustainable preservation of important plants should not be undervalued.

Fifth, the function of the horticultural nursery is necessary but not sufficient. Burle Marx himself advocated many times the fundamental need of training good gardeners to insure the project life through time. In Brazil, as in other developing countries, there is no established tradition of gardening as in Europe or USA. From my experience in the Caribbean, which I believe may be quite close to the situation in Brazil, anybody able to handle a machette to chop trees, a lawn mower and a broom to sweep away dead leaves and organic matter from the ground (including precious topsoil) call himself a gardener. Burle Marx personally started a generation of gardeners who were responsible for the maintenance of the sitio and other private gardens. He even said he wanted courses on aesthetics to be taught at the sitio for gardeners in order to help refine their judgement and understanding of good design. The legacy of his landscapes is fundamentally tied to trained personnel that understand the specific way he liked, for instance, a tree to be gently pruned, or the way dead leaves of certain palms and yucca should not be eliminated but hang down covering their trunk, or the way a bed of bromeliads should be left alone in its fullness and majestic dense clusters rather than separating the plants and space them apart to avoid competition. Are gardeners been trained today with the knowledge and the sophisticated appreciation of nature that Burle Marx had? Are they trained in a way that they could make wise decisions on their own as unexpected problems to be solved arise?

Sixth, as I already mentioned for Marambaia and Vargem Grande, Burle Marx had the capacity to wait and imagine his landscapes change in time. He would prefer to plant small tree specimens a few 
feet tall rather than large ones, as they would establish themselves more successfully in the long run, especially in the harsh conditions at the Aterro. Large specimens as we are used to see today in the implementation of gardens and parks in the United States or Europe would be unthinkable in Brazil in the 1940s and 1950s. Large plants (such as coconut palms) were available for Park Flamengo only if reclaimed in Rio during the conversion of garden properties into apartment building real estate. But I am sure that given a price, and having a choice, Burle Marx would prefer to buy ten small trees rather than a large one, as he needed several plants from the same specie for his grouping design. Also, because they were small trees, he could move them easily around in the park during construction, and could adjust the design to perfection. It was not an exception for him to ask the trees to be dug up and planted all over again. This happened many times during the construction of both parks, especially in Parque del Este. Today, in the reconstruction of Park Flamengo, small palms and trees are still being used. If on the one hand this seems to continue Burle Marx's legacy, on the other new problems are now posed by the fact that the crowd of visitors do not notice nor care about the little trees, and perhaps better tree protection should be devised. I have seen many just transplanted palms less than $50 \mathrm{~cm}$ high being smashed by people playing soccer among them. Moreover there is a visual problem of unbalance when new small plants are integrated among a group of mature ones. For instance, the Corypha tagliera palms that died after flowering between the MAM and the Monument, have been interplanted by seedling only a few centimeter high, leaving a few voids in the palm row that will be noticeable for many years. Perhaps new palms should have been planted many years ago in between the near to mature Corypha, as was done in the Rio Botanical Garden by inter-planting new royal palms along the row, and this strategy should be kept in mind and practiced ahead of time in every area of the park where trees and palms are planted more formally and will mature and die in future years.

Seven, Burle Marx believed that the role of the designer should not be restricted, as he said, to "executing projects". An equally important responsibility was that of a proactive participation in the preservation and conservation of the environment at municipal or regional level. The choice of native plants in the specifications of a project such as Flamengo or Parque del Este would thus be part of this larger endeavor: beyond a pedagogical intention or personal aesthetic, it would in fact save many plants from the danger of their extinction in their natural habitat. In his travel to study and collect plants, Burle Marx 
directly experienced the sheer magnitude of deforestation and unsustainable development taking place in many environmentally sensitive areas of Brazil. This compelled him to become, since the late 1950, one of the most dedicated and incisive advocates against the destruction of Brazil's ecological endowment. He directed accusations against lumber companies, polluting industries, deforestators and arsonists, predatory fishermen and hunters, and went public on the daily papers many times with his direct accusations. This commitment was influencing with concrete agendas his life-long project of relating closely two different conceptual realms and scales of intervention - the garden and the larger natural environment - making one meaningless without the other. With today's professional specialization that separates garden and park design from urban design or regional planning, a design activity at different scales reinforced by a committed environmental advocacy (which were so typical in Burle Marx's approach) seem quite hard to accomplish or preserve in homage of its legacy. Burle Marx was not just looking at native plants - how to save and collect them, how to cultivate them in gardens - he was constantly fighting unsustainable development. I probably would not engage the kind of mitigation or compensatory projects that we embrace today in our contemporary practice, especially if they could potentially become instruments of real estate speculation on sensitive habitats.

\section{The Sítio Burle Marx: An Endangered Masterpiece}

I wish now to make a few comments regarding the Sítio Roberto Burle Marx and its controversial preservation (Figures 19 and 20). In order to address the "conceptual ideas" that would help preserve the sitio, we should start by asking, "what is the sitio, what is its mission?" There are at least three possible definitions for the sitio.

First, it is a series of gardens, greenhouses and buildings with plants and art collections donated to the government, to be preserved as a whole. This is how Burle Marx described the sitio when he donated the entire property to the Brazilian government in 1985, nearly ten years before his death. There is a clause in the document where Burle Marx requests specifically that this donation implies the preparation of an inventory of all plants existing at the sítio, as the first step for any management or maintenance program. This inventory has not been done yet, while the management of the sitio has included many serious and deliberate changes of the gardens and collections since Burle Marx's death. 


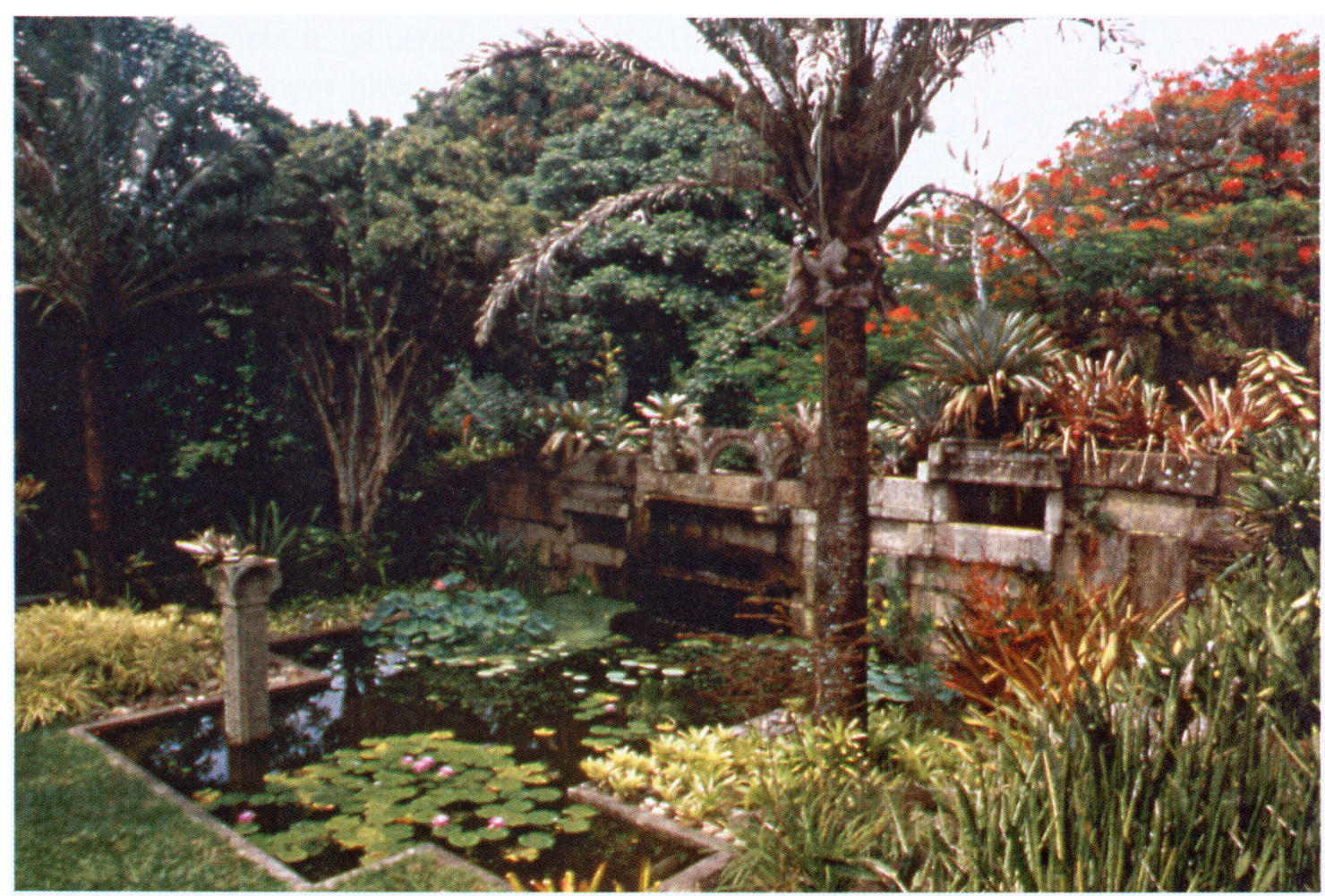

Foto 19 - Sítio Burle Marx

Crédito: Autora

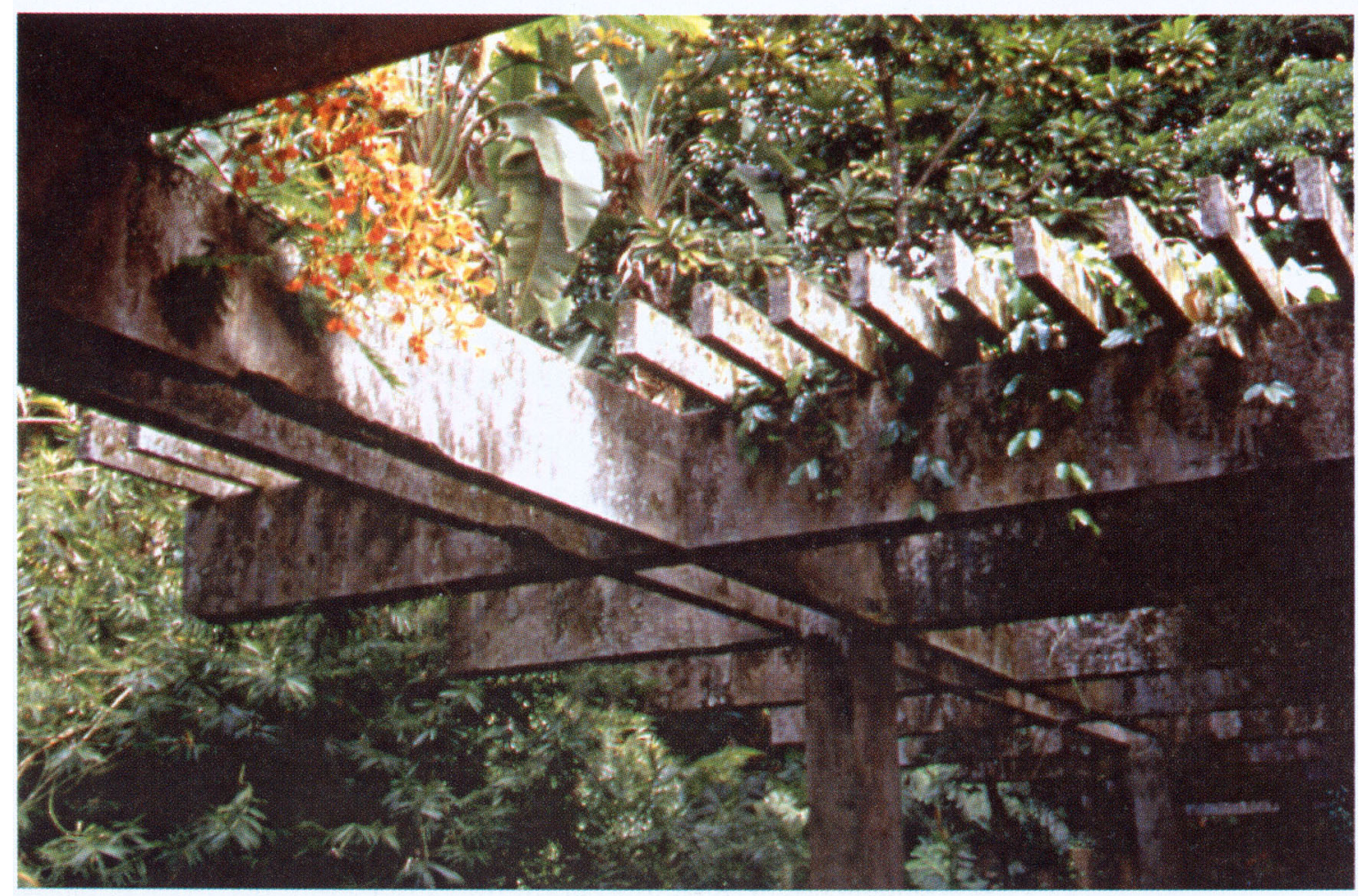

Foto 20 - Sítio Burle Marx

Crédito: Autora 
Second, a National Monument. This is another definition that is congruent with the first, as the sitio changed its status from that of State to National Monument in 1985. Yet the legal process has not been completed by IPHAN, and the sitio is, paradoxically, after 15 years of its nomination, still not registered and listed in the Brazilian book of National Monuments. This paradox compromises its status of historic garden, which depends on its official identification and listing.

Third, a place for perpetuating species doomed to disappear in their natural settings. Burle Marx said in 1989 that he wanted in the sitio to set living examples, through its gardens, and through the organization of didactic activities (such as courses and seminars on botany, horticulture and landscape architecture) on how to use native flora in design. These activities would be, he said in an interview, for interested people in general, as well as for future botanists and students of landscape architecture. This statement excludes the possibility to transform the sitio in a tourist destination, which will be inevitable if the current plan waiting for funding will be built. This plan proposes to transform the sitio in a sort of eco-park - with a cable car leading visitors up the hill and viewing platforms over new gardens never existing before on the hillside that have already been partially planted. Several trees will have to be cleared to allow the cable car structure to be built. The plan calls also for a plant market, playground areas, a butterfly and aquarium facilities built in a piece of land currently belonging to the Army opposite the road.

The Florence Charter of Unesco on historic gardens should be a clear reference for preservation policies that would be true to any of these three definitions of the sitio essence, scope and mission. The article n. 15 of the Charter, for instance, states that

"no restoration work and, above all, no reconstruction work on an historic garden shall be undertaken without thorough prior research to ensure that such work is scientifically executed and which will involve everything from excavation to the assembling of records relating to the garden in question and to similar gardens. Before any practical work starts, a project must be prepared on the basis of said research and must be submitted to a group of experts for joint examination and approval".

The sitio instead is managed with no plant inventory of the collections and design of the gardens and greenhouses. The greenhouse collections, which were among the most important in Brazil for native species, are today in disrepair and no botanist is coordinating the work 
done to catalogue and reproduce the species. Moreover, no mapping activity and drawings are developed to record the plant inventory in graphic form for maintenance and preservation purposes. Additionally, no rules and regulations exist to bind any decision being made, no management plan or project plans are approved before execution by an appointed committee, and no supervision is done by a committee of experts. The existing Consulting Council of the sítio, composed by well-known experts and friends of Burle Marx, does not seem to be able to fulfil its purpose of supporting the technical decisions because their meetings are very brief and not as frequent as they should be (only one meeting in the last two years and a half). Above all, what is it to be decided in these short meetings when there is no plan or regulation to be evaluated? I have visited the sitio regularly since 1995, since originally I was thinking to document the sítio gardens in detail for developing new drawings, preoccupied that nobody was doing an inventory of its rare plants and their location. The changes that I have seen in these visits overtime are dramatic, even though for those people who are not familiar with the planting and the gardens details the changes go unnoticed.

The Art. 11 of the Florence Charter states that the "preservation of an historic garden in an unchanged condition requires both prompt replacements when required and a long-term program of periodic renewal, such as clear felling and replanting with mature specimens of the same kind." In the sitio, on the contrary, the scarce financial resources are used to fell trees for personal aesthetic or functional reasons, without a project proposal and before an inventory or a plan is being made. Moreover, mature and important plants are removed from their original location in the gardens in order to create new gardens with those plants in areas that were never planted as garden before (Figures 21, 22, 23, 24, 25, 26 and 27). For instance, the gardens around the Main House were only worked by the more experienced chief gardeners under the direct supervision of Burle Marx himself. With no plan, with no inventory of the original design of these gardens, and without the chief gardeners that have already retired, these gardens are not only being cleaned and apparently maintained but are actually suffering from what I would call "clandestine operations of change". This is justified by the management as what has been called a "casuísmo estratégico criterioso" or a "método burle-marxiano por excelência" which is a rhetoric that misuses and misinterprets the right of Burle Marx to change or modify himself, as part of his design process, but not the right of others. This rhetoric is being used to bypass the need to do the inventory and the management plan of the sítio, by finding 
excuses to argue that a management plan is a loss of time and an inconvenience.
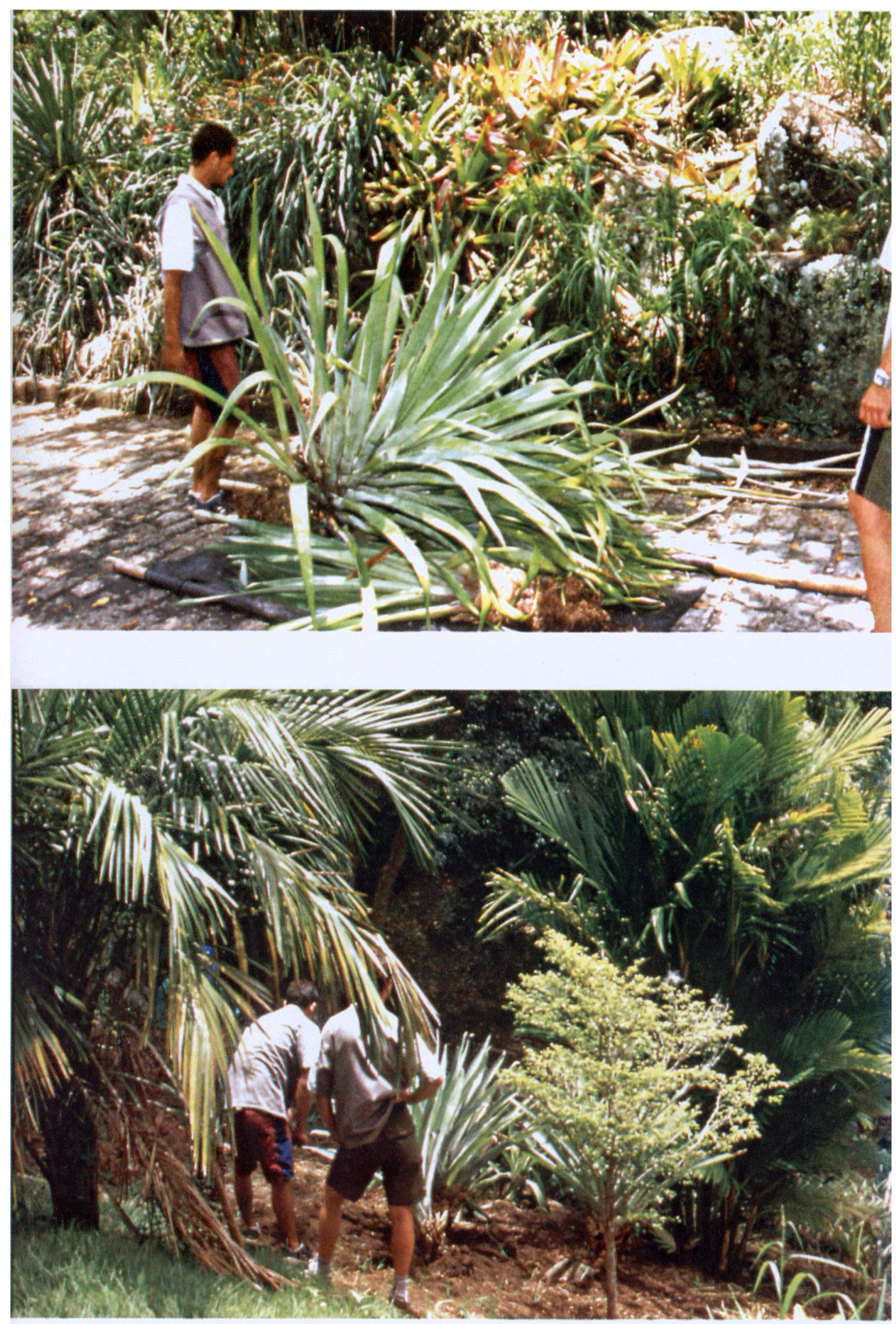

Fotos 21 e 22 - Sítio Burle Marx/2000 

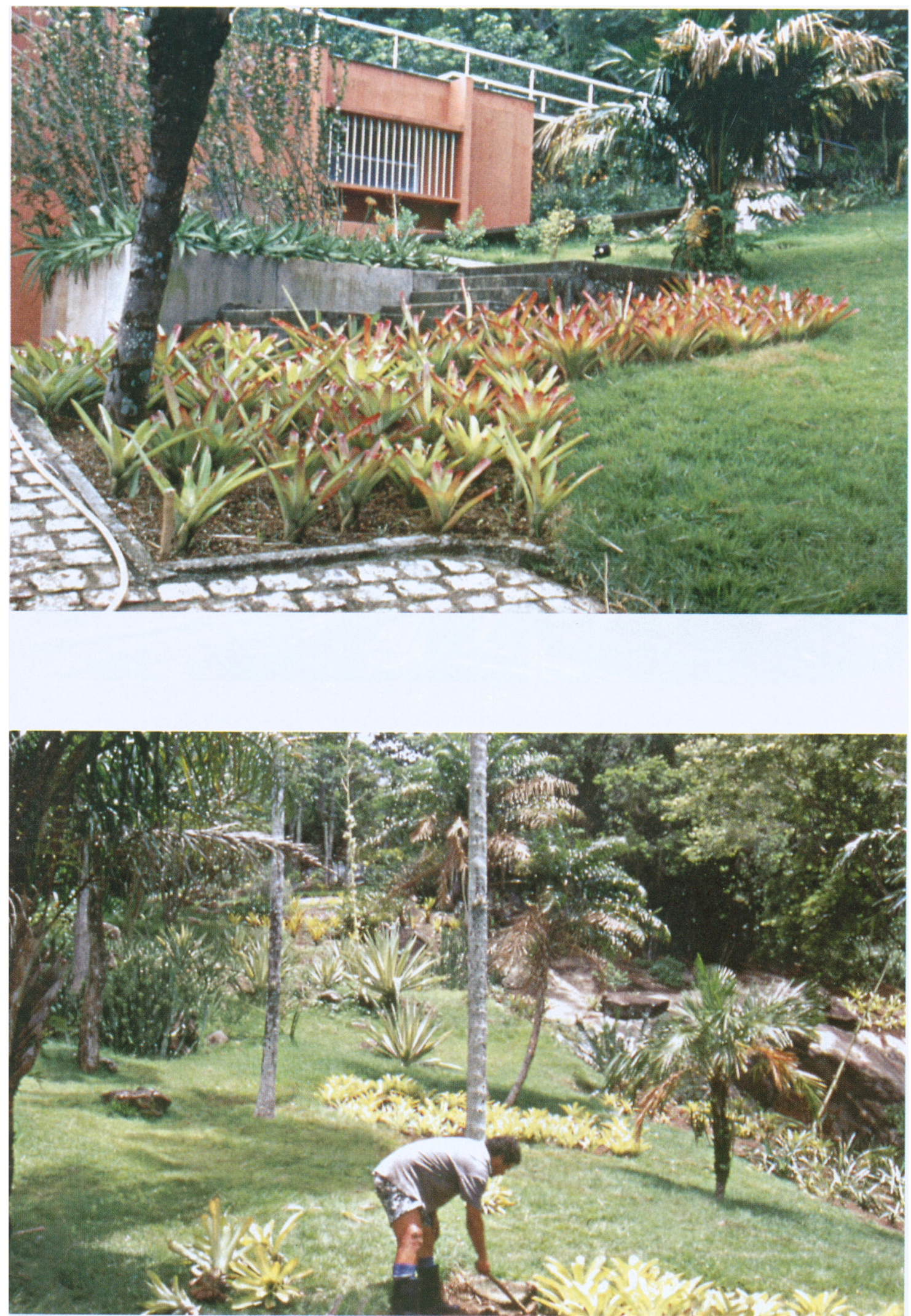

Fotos 23 e 24 - Sítio Burle Marx

Crédito: Autora 

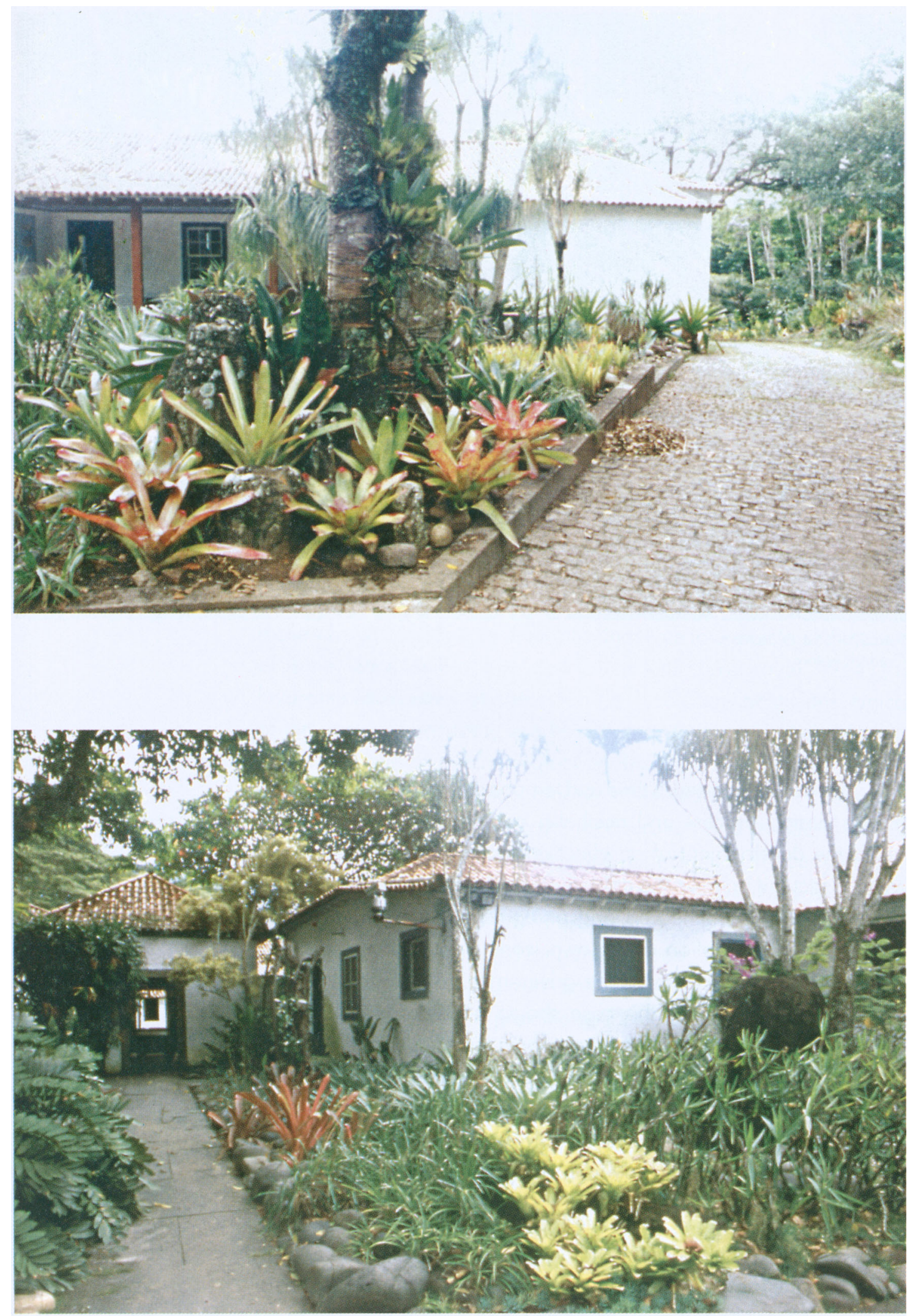

Fotos 25 e 26 - Sítio Burle Marx

Crédito: Autora 


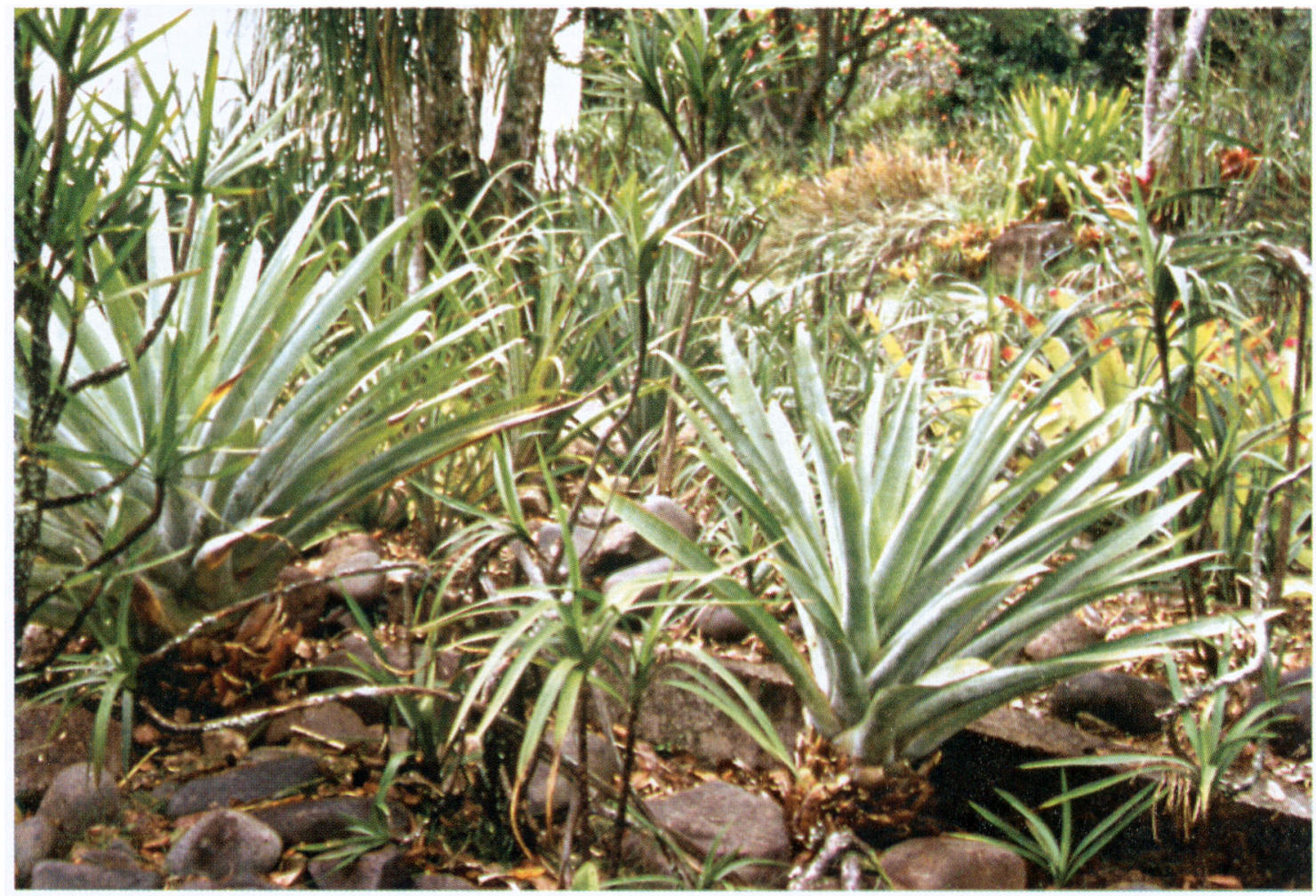

Foto 27 - Sítio Burle Marx

Crédito: Autora

This is a clear case in which time and temporality, so important in Burle Marx's design process and aesthetic, are dangerously misused to avoid the development of an effective preservation strategy. Burle Marx in fact did not give the right to others to use his sítio as a testing ground for their unchecked and unregulated intuitive and artistic process of interpretation of his own work, because he specifically donated the sítio property to the government in order to insure its preservation. Change in this case should be seen as a source of concern rather than a welcomed quality in the sitio landscape, since change here is being imposed by drastic actions and personal judgement that are excluding any evaluation and approval by experts. Moreover, change is not being documented as part of an explicit management plan, thus is going on completely unchecked.

In conclusion, I have only introduced some of the complexities we face in developing a methodology that will successfully and strategically preserve Burle Marx's work. Many of his projects, such as the Aterro or Parque del Este, started going in decline and went in disrepair at the very moment they were finished, because of non sustained maintenance 
policies, political interest, and intellectual support from an elite of cultural leaders. Other projects were never funded and completed for the same reasons. Others, like the sítio, after reaching a mature state of complexity and beauty, are dramatically and quickly disappearing in front of our eyes, and we seem not being able to do anything about it. Only a limited number of projects followed the evolution that Burle Marx had hoped, developing in time in the mature landscapes he had envisioned. Whereas his private projects depended on the continuity of ownership and the possibility to maintain his design through family generations, his public projects depended, and still depend today, on the continuity in the political support from public administrations and cultural institutions, which is so difficult in Brazil. In the years 1935 1960s, Burle Marx developed and refined his design process and approach with projects that exemplify his complete career. In this period, in Brazil and elsewhere in Latin America, public authorities and national government turned to architecture, park and open space design and public art as iconic expression of cultural and national ambition. Key leaders such as a Gustavo Capanema, Carlota Macedo Soares, Carlos Lacerda, or Juscelino Kubischek are among those who were necessary in Brazil at that time to understand the vision of Burle Marx, embrace it, and implement it. Yet, after 1964, the favorable association of intellectuals and visionary politicians, typical of the post-war decades, was forever lost in Brazil. Today, after the many decades of public neglect of Rio open spaces and cultural monuments, Major Conde among other leaders have played an important role in sponsoring the recuperation and restoration of an important legacy. But there is so much to be done in this beautiful and culturally rich country. I believe an intellectual and cultural elite needs to be formed again in Brazil, a group of leaders willing to focus and work in the public realm and for public interest, a task so difficult today in our increasingly privatized and consumerist society. University scholars, educators and practitioners should promote alliances with governmental institutions and political authorities, providing expertise and serious research methodologies to help the development of interpretation and conservation strategies of Burle Marx's work. 